\title{
AS FORTIFICACIÓNS MODERNAS DO RÍO MIÑO. REFLEXIÓNS SOBRE DIFERENTES ESTRATEXIAS PARA A SÚA POSTA EN VALOR
}

Rebeca Blanco-Rotea

Grupo de investigación Síncrisis

(Universidade de Santiago de Compostela)

DOI: 10.17075/pvpcr.2021.009 



\section{INTRODUCIÓN. O RÍO, UNHA GUERRA, UNHA PAISAXE CULTURAL}

O río Miño é o río mais importante de Galicia. Nace no Pedregal de Irimia, na serra de Meira, no nordeste da provincia de Lugo, e desemboca no océano Atlántico, entre as poboacións da Guarda (en Galicia) e Caminha (en Portugal), percorrendo, polo tanto, practicamente toda a xeografía da comunidade galega. $\mathrm{O}$ interese por este río no presente texto vén da súa condición de fronteira natural nos seus últimos $76 \mathrm{~km}$ entre España e Portugal, un espazo coñecido como Baixo Miño en Galicia e Alto Minho no país veciño. Nós referirémonos a el cando falemos do espazo común como o val do Miño ou a fronteira miñota.

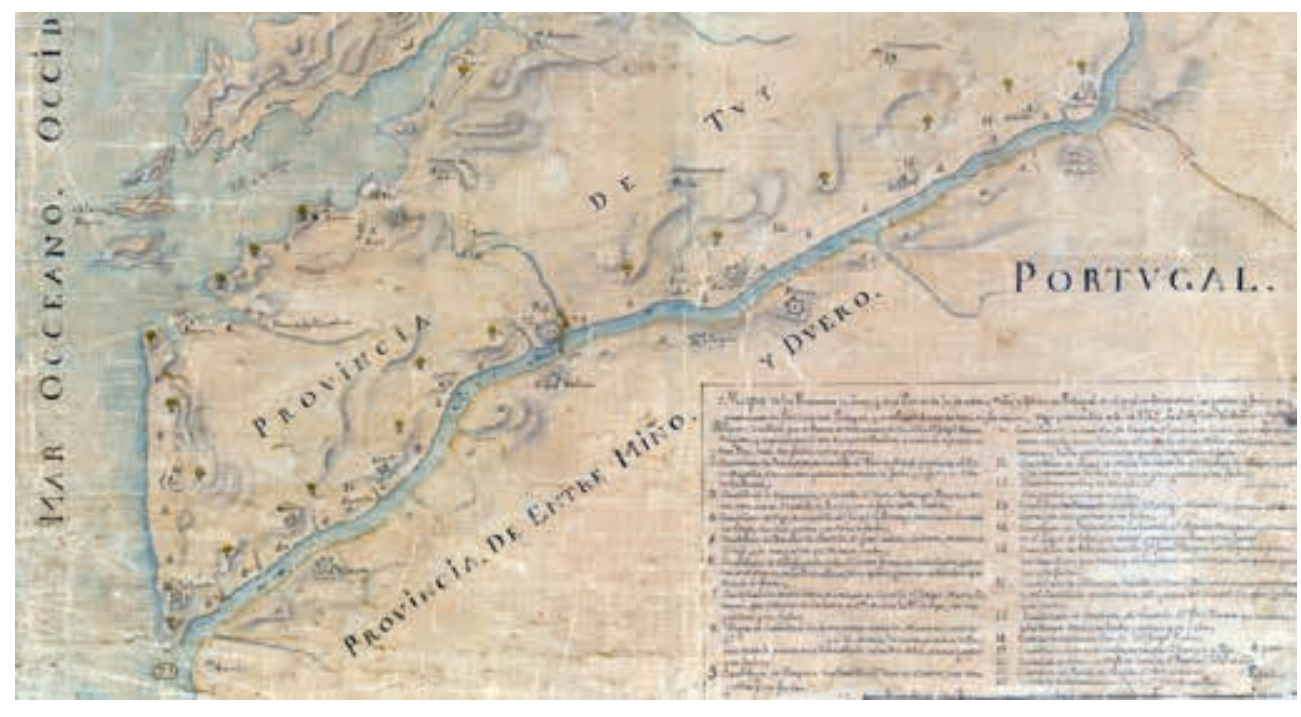

Figura 1. Mapa da antiga provincia de Tui, entre o Douro e o Miño, onde veñen sinaladas as garitas e fachos. D. Alexandro de Anglés, 1762, (C) Centro Geográfico del Ejército

Esta fronteira tivo un especial interese durante o período transcorrido entre 1640 e 1668, momento no que tivo lugar a Guerra da Restauración entre o Reino de Portugal e a Coroa de Castela, tras a proclamación como rei João IV (1640-1656) do duque de Bragança, cabeza dunha antiga familia nobre portuguesa e descendente de João I de Portugal. Con motivo deste proceso bélico, o espazo localizado no último tramo do río Miño, que contaba cunha serie de castelos e torres medievais localizadas estratexicamente nas zonas de pasos sobre 
o río, foi transformado durante a guerra e con posterioridade a ela, o que deu lugar a unha paisaxe fortificada á moderna, cuxo elemento máis significativo será a realización dunha serie de fortificacións de planta abaluartada tanto de carácter permanente coma de campaña, que, ao longo destes $76 \mathrm{~km}$, interactúa co río Miño, cos seus pasos, coas vilas e cidades que se atopan na súa beira, e coas serras que pechan o val polo norte e polo sur (figura 1). Hoxe, esta paisaxe e os elementos que a conforman constitúen un dos conxuntos patrimoniais fronteirizos máis ricos e interesantes que temos en Galicia. Neste texto, que se corresponde co relatorio impartido o día 7 de novembro de 2018 nas xornadas "A posta en valor do patrimonio cultural dos ríos: Galicia e outros exemplos», organizadas polo Consello da Cultura Galega, reflexionaremos sobre a súa relación co río, sobre a súa condución como elemento patrimonial e sobre a súa posta en valor.

\section{O ESPAZO FRONTEIRIZO DO RÍO MIÑO}

O último tramo do río Miño constitúe a fronteira hispano-portuguesa nun espazo denominado A Raia Húmida, que abarca, ademais do propio val a ambos os dous lados do Miño constituído por unha planicie aluvial, unha zona de ascenso cara a unha serie de bandas montañosas que pechan este espazo polo leste (a serra do Suído, en Galicia, e da Peneda-Gerês, en Portugal), o norte (serra do Suído, montes da Paradanta, serra do Galiñeiro, serra do Galleiro, serra do Argalo e serra da Groba), o sur (serra da Peneda, serra da Boulhosa, serra Pequena, serras da Gávea, Salgosa e Covas, e serra da Arga) e o oeste (a serra da Groba, en Galicia, e a serra da Arga, en Portugal); estas serras coinciden topograficamente coas alturas elevadas da dorsal meridiana (Santos e Santos, 1996: 385) (figura 2). O río desemboca no océano Atlántico e a súa desembocadura é un lugar de acceso cara ao interior deste espazo. Desde un punto de vista xeográfico, hai aspectos relevantes, como a topografía, que terán unha importante repercusión na conformación da paisaxe fortificada que se analiza neste texto, pois deles dependerá a selección da localización das fortificacións, a visibilidade e a visibilización entre entidades ou a facilidade de tránsito a través deste territorio. A pesar da existencia dunha división tanto física coma administrativa neste espazo, as características xeográficas presentan bastantes similitudes a ambos os lados da fronteira. Tanto 
para Galicia coma para Portugal, o río Miño constitúe o eixe vertebrador da vida neste territorio. Neste traballo, é importante a análise da relación entre o espazo físico e os elementos que se construíron durante o proceso de fortificación, pois a paisaxe non deixa de ser a interrelación entre dous fenómenos: por un lado, o puramente natural que corresponde á propia estrutura do medio e, por outro lado, o eminentemente antrópico que contribúe á transformación dese medio.

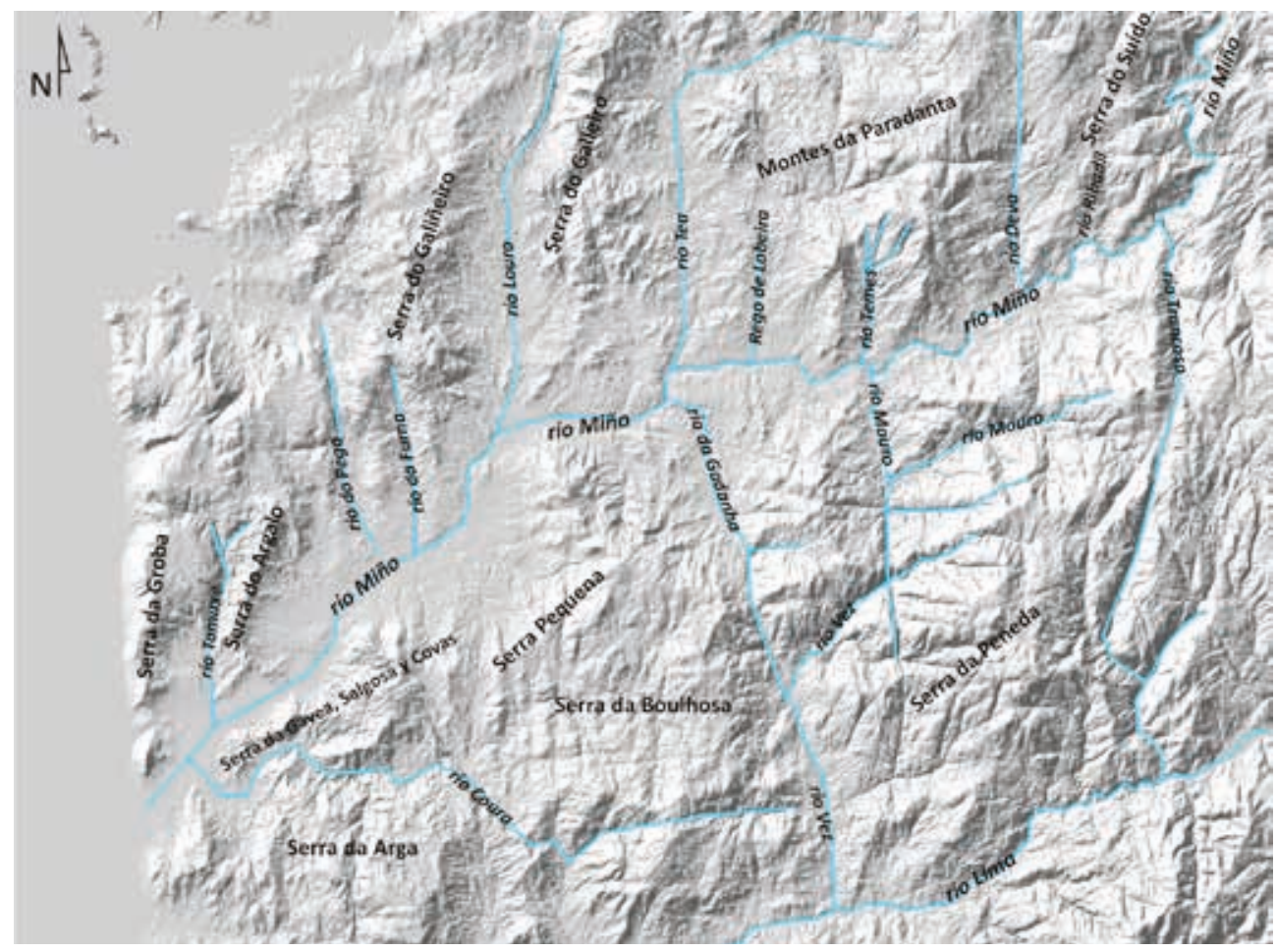

Figura 2. Modelo Dixital de Elevacións (MDE) da área de estudo Raia Húmida, coa localización das zonas montañosas e de serra, e da rede hidrográfica principal

O río Miño desemboca entre as poboacións de Caminha e A Guarda formando un amplo estuario que se caracteriza por unha importante presenza de areais que, co tempo, acaban formando pequenas illas; chama a atención a diferenza que constatamos ao comparar as cartas náuticas doutras épocas coas imaxes satélite actuais deste tramo do Miño pola variabilidade que se documenta nestas illas, aspecto que debe terse en conta xa que puido influír na variación dos pasos ao 
longo do curso baixo do río e, en consecuencia, das zonas que se debían controlar dentro del (figura 3). Este espazo conta con diversas áreas de grande importancia ecolóxica que están actualmente protexidas ${ }^{1}$. Os últimos $80 \mathrm{~km}$ do Miño, desde o embalse de Frieira, en Crecente, até a desembocadura, e algúns afluentes, como o Tea e o Tamuxe (en Galicia) e o Coura (en Portugal), están amparados en ambas as marxes dentro dun espazo transfronteirizo que pertence á Rede Natura. A orografía da zona fai que existan ademais unha serie de atalaias naturais que serviron para o control do territorio, coma o monte Santa Trega ou o Aloia, que é Parque Natural (en Galicia), e os montes Espiga, San Paio ou Gois (en Portugal), que foron ocupados como fachos desde os que prender luminarias que formarán parte da paisaxe fortificada que nos interesa.

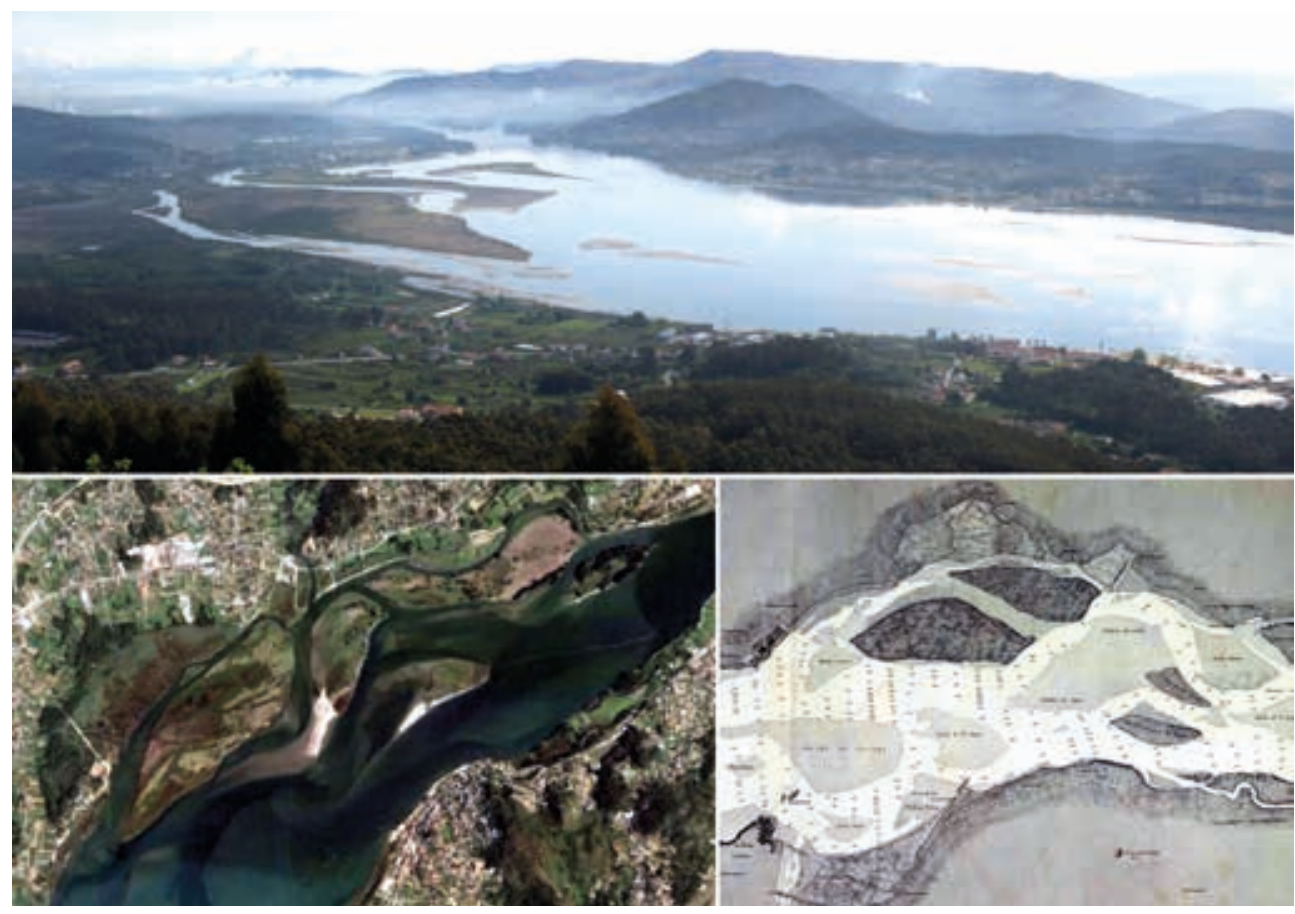

Figura 3. Areais que se forman na desembocadura do río Miño: arriba vistos desde o monte Santa Trega; abaixo á esquerda, imaxe satélite da misma zona (Google Earth 2013); á dereita, parte da Carta Náutica del Río Miño de 1885 de Rafael Sociats y Arricant (Sala Goya. Cartografía, Sede Recoletos, MR/22 H. 0901). Nestas dúas últimas imaxes, pódese observar a variación dos areais entre finais do século XIX e a actualidade

1 http://fortalezas.valedominho.pt/gl/enquadramento_ambiental.html, consulta de maio de 2011. 
O río é navegable até Valença do Minho-Tui, aínda que tamén pode chegarse a Salvaterra-Monção, como mostran as representacións de embarcacións subindo polo Miño xa desde a época baixomedieval, pero tamén as cartas náuticas que se conservan. A partir destas dúas últimas poboacións, o río estréitase e proliferan os afloramentos rochosos, ademais das pesqueiras ${ }^{2}$, discorre máis encaixado e aumentan os meandros, o que dificulta a navegabilidade. Este aspecto hai que relacionalo co cambio da orografía no tramo máis oriental do curso baixo do Miño.

O relevo do último tramo do río Miño presenta unha gran variedade e está caracterizado pola diversidade e a fragmentación (Santos e Santos, 1996: 382); é un sector no que se combinan o val do Miño, que ten unha orientación nordeste-suroeste, e os vales perpendiculares a el dos ríos Deva, Temes, Tea, Louro e Tamuxe (en Galicia), e Trancoso, Mouro, Gadanha ou Coura (en Portugal), que aproveitan precisamente esas intensas fracturas do terreo e descenden dunha serie de serras (Pérez Alberti, 1986b: 404). Neste último tramo alternan sectores que superan os 1000 metros de altitude con outros que se localizan ao nivel do mar. Pechando o val do Miño polo norte e o sur localízanse senllas bandas montañosas que corresponden a distintas serras (Pérez Alberti, 1986b: 386): no caso galego, os montes da Paradanta e as serras do Galleiro, Argalo ou Galiñeiro e, no portugués, as serras da Peneda, Boulhosa, Gávea, da Salgosa, da Cova ou da Arga; esta disposición entre cadeas montañosas fai que esta zona teña unha alta pluviosidade e nebulosidade. Ao mesmo tempo, de leste a oeste está conformada por unha sucesión de interfluvios montañosos e vales fluviais profundos ${ }^{3}$. Os primeiros teñen unha dirección norte-sur no caso galego, e sur-norte e leste-oeste no portugués, e presentan orografías elevadas con vertentes raídas que culminan en planicies descontinuas en Galicia (ib.) e en practicamente unha única planicie en Portugal, situada entre a liña de ruptura cara ao Miño das serras e o río Lima.

2 Grandes muros construídos en pedra que penetran no río desde os que se pesca a lamprea. Este tipo de construcións remóntanse polo menos á época altomedieval (Viveen, Sanjurjo-Sánchez, Goy-Diz, Veldkamp e Schoorl, 2014). Na zona estudada en Chan de Vide (As Neves), no contorno da Outal de Medáns, os sedimentos formados polas pesqueiras remóntanse ao século VIII.

3 Este tipo de relevo é característico en Galicia, onde se produce unha combinación de horizontalidade, superficie de aplanamento, e verticalidade, representada polos vales fluviais, orixinando multitude de paisaxes diferentes (Pérez Alberti, 1986a: 22). 
Os vales fluviais, aínda que profundos, son anchos co fondo aplanado (ib.); cara á zona máis oriental, os vales son cada vez máis encaixados, coma no caso do río Mouro (en Portugal). Este espazo será ocupado polos sistemas defensivos que veremos máis adiante. De feito, esta sucesión de montañas e vales van condicionar historicamente a disposición dos distintos núcleos de poboación no val do Miño, pero tamén constituirán un elemento chave na elección e distribución das fortificacións ao longo deste territorio. Estes aspectos, entre outros, serán o xermolo da construción na época moderna dunha serie de conxuntos fortificados que responden a aspectos que están moi relacionados coa existencia desta rede de poboamento previa, duns sistemas defensivos precedentes ou da propia articulación do territorio, como veremos.

\section{O ESPAZO DA GUERRA}

A fronteira histórica hispano-portuguesa deseñouse ao longo dos séculos XII e XIII, e quedou practicamente configurada desde 1297 co Tratado de Alcañices. Desde época temperá, a realeza buscou puntos de apoio para a súa estratexia de empoderamento político-administrativo (Andrade, 1998), incentivando a construción de núcleos de poboación nas marxes do río Miño, que constituía unha importante vía fluvial de penetración cara ao interior de ambos os dous reinos desde o océano (en sentido oeste-leste), do mesmo modo que, en paralelo a este por ambas as súas marxes, circulaba unha vía terrestre que unía as principais poboacións agora consolidadas. Pola súa vez, existen outras vías que atravesan o territorio en sentido norte-sur salvando o río Miño a través dos pasos de barcas (Almeida, 1968; Almeida, 1984; Andrade, 1994: 271-274). É precisamente nas zonas nas que se localizan estes pasos xa históricos (Ferreira, 1988; Andrade, 1994: 274) onde foron xurdindo os núcleos de poboación máis importantes da fronteira ao longo da Idade Media, que foron fortificados nos séculos XII e XIII. De aí a presenza de poboacións enfrontadas a un e outro lado da fronteira que se irán consolidando co tempo, amurallándose ou construíndo nelas un castelo propiedade do monarca, ou dominando a rede viaria que ordenaba a rexión (Andrade, 1994: 329). Iníciase así a fortificación da Raia. A este momento pertencen núcleos como Caminha, Valença ou Melgaço (en Portugal) ou Tui e Salvaterra 
(en Galicia) (Pallares, 1987; Pallares e Portela, 2015: 140). Esta paisaxe defensiva concentrábase nos núcleos de poboación situados en zonas de paso sobre o río Miño, condicionando a estrutura defensiva que se desenvolveu en época moderna, cando a fortificación anterior era insuficiente ante os avances da artillaría e a nova articulación dos exércitos da época (Parker, 2002).

A Guerra da Restauração ten lugar entre o 1 de decembro de 1640, cando o duque de Bragança é proclamado en Lisboa rei de Portugal como João IV, e o ano 1668, cando se firma o Tratado de Lisboa, que supuxo a independencia de Portugal, reino anexionado ao Imperio Hispánico desde 1580 por Filipe II. O 1 de decembro, devolve a nación lusitana a estado primitivo e restáurase a súa condición de reino per se (Silva, 1862: 3; Bouza, 1991, 1993; Almeida, 2013).

Entre 1640 e 1668, as campañas de guerra foron descontinuas espacial e temporalmente, e dependían das dispoñibilidades loxísticas de persoal e material. Foi unha guerra con escasos medios e especialistas, cunha grande importancia táctica da artillaría, as armas de infantaría e os enxeñeiros, na que exerceu un especial papel a construción dunha serie de fortificacións abaluartadas sobre todo de campaña (Costa, 2005; CADIVAFOR, 2008: 8; Almeida, 2013). A actividade bélica foi acompañada dunha importante actividade construtiva grazas á modernización das defensas de ambas as dúas frontes, a toma de posicións no país contrario e a importante transformación da arquitectura e a paisaxe precedentes. Se ben é certo que, nos grandes núcleos urbanos que xa contaban cunhas defensas previas, a actividade é case constante desde o inicio da guerra, naqueles lugares onde as fortificacións se realizan ex novo neste momento, a actividade construtiva coincide con episodios concretos da contenda que afectan a zonas determinadas. Por exemplo, os galegos ocupan o contorno de Salvaterra con fortificacións de campaña unha vez conquistada a vila polos portugueses e iniciada por eles a súa modernización: neste caso teriamos un castelo medieval que se abaluartúa neste momento e a construción ex novo dunha defensa de campaña por parte do exército galego para cortarlles o paso aos portugueses de cara a Tui.

Cando, en 1668, se firma o Tratado de Paz de Lisboa, Portugal alcanza a súa independencia e establécense as fronteiras que se manteñen practicamente intactas até a actualidade. Cada país devolve ao outro as prazas conquistadas no territorio veciño, pero a modernización defensiva das cidades continúa e as fortificacións permanentes finalízanse ao longo dos séculos XVII e XVIII. 


\section{A PAISAXE FORTIFICADA}

O concepto de paisaxe manexado neste texto compréndea como a interrelación entre dous fenómenos, un puramente natural que corresponde á propia estrutura do medio e outro eminentemente antrópico que contribúe á transformación e obxectivación dese medio (Criado-Boado, 1999: 5). Este concepto recolle as recomendacións do Convenio Europeo da Paisaxe que a entende como «calquera parte do territorio tal como a percibe a poboación, cuxo carácter sexa o resultado da acción e a interacción de factores naturais e/ou humanos». O debate sobre a evolución deste concepto desde a arqueoloxía foi amplamente tratado por outros autores (Wittlesey, 1997; Knapp e Ashmore, 1999: 8-13; Criado-Boado, 1999: 5-6; Anschuetz, Wilshusen e Scheick, 2001: 160-168; Heilen, 2005: 14-39). No noso caso, propuxemos unha tripla conceptualización, entendendo a paisaxe como a materialización dun concepto resultado dun proceso e recurso do pasado no presente (Blanco-Rotea, 2017). Esta conceptualización está baseada na matriz empregada por Criado-Boado que representa a ontoloxía do Patrimonio Arqueolóxico nas súas tres dimensións como documento (do pasado), como obxecto (do pasado no presente) e como recurso (no presente) (Criado-Boado, 2012: 193-194), pero tamén no paradigma de paisaxe de Anschuetz, Wilshusen e Scheick (2001) rexido por catro premisas:

1. Landscapes are not synonymous with natural environments. [...] 2. Landscapes are worlds of cultural product. [...] 3. Landscapes are the arena for all of a community's activities. [...] 4. Landscapes are dynamic constructions, with each community and each generation imposing its own cognitive map on an anthropogenic world of interconnected morphology, arrangement, and coherent meaning. (Anschuetz, Wilshusen e Scheick, 2001: 160-161)

A partir deste marco teórico, determináronse aqueles conceptos que serán a base da nosa investigación sobre a paisaxe fortificada da fronteira en época moderna ${ }^{4}$.

4 Estes conceptos foron definidos na tese de doutoramento da autora (Blanco-Rotea 2015) e recollidos en Blanco-Rotea, 2017. 
A paisaxe fortificada defínese como unha paisaxe cultural na que se insire algún tipo de arquitectura cuxa organización responde a unha estratexia defensiva concreta, polo que se organiza ou articula nun ou varios sistemas defensivos. O Plan Nacional de Arquitectura Defensiva Español ${ }^{5}$ considera que «A arquitectura defensiva forma parte indisoluble da paisaxe cultural na que se insire e á que caracteriza. Os elementos que compoñen esta arquitectura están relacionados entre si dentro desa paisaxe e, en consecuencia, deberán ser tratados como agrupacións completas de sistemas xerais defensivos, con metodoloxía similar». Segundo esta definición, paisaxe fortificada e arquitectura defensiva deben entenderse de forma conxunta e analizarse de forma conxunta, sendo necesario desenvolver programas de investigación e propostas metodolóxicas que atendan ambas como parte dunha mesma realidade.

A arquitectura implántase nun espazo físico ao que articula, conformando unha paisaxe na que se materializan as formas de pensamento da sociedade que executa esa arquitectura, no noso caso, os principios da fortificación abaluartada ${ }^{6}$ e a lóxica barroca. No entanto, pola súa vez, a arquitectura debe adaptarse ao medio físico. Os principios da fortificación abaluartada deberán adaptarse ao lugar no que se implanta cada fortificación, serán tidos en conta na relación que se establece entre a fortificación e o espazo físico, e entre a fortificación e outras arquitecturas que poden formar parte do mesmo sistema defensivo (Matos, 2016: 35-36).

O sistema defensivo analizado nesta investigación baséase na articulación e control de distintas unidades territoriais (figura 4) denominadas subsistemas ou conxuntos defensivos ${ }^{7}$ (Blanco-Rotea, 2011b). A nosa formulación parte da hipótese de que nelas a defensa funciona como un organismo autónomo pero conectado a través de determinados mecanismos ${ }^{8}$ cos subsistemas contiguos, de maneira que os subsistemas acaban formando parte dunha estrutura maior: o

\footnotetext{
http://www.mecd.gob.es/planes-nacionales/eu/enlaces/plan-nacional-arquitectura-defensiva.html

6 Fernández de Medrano, 1700; Lucuze, 1772.

7 Sobre os conceptos de sistema e subsistema xa argumentamos en Blanco-Rotea, 2011b: 148-149. Para ampliar o modelo conceptual da paisaxe fortificada do Miño no que se explican e definen todas as entidades arqueolóxicas que o conforman, véxase Blanco-Rotea, 2015: 146-157. Sobre outras definicións e conceptualizacións de sistemas defensivos, véxase Cobos, 2005 e Cobos-Guerra, 2011.

8 Como as estructuras de relación, aquelas que comunican dúas entidades arqueolóxicas (fortificacións el ou subsistemas) entre as que non existe unha relación de visibilidade directa. Unha estrutura de relación sería, por exemplo, un facho (Blanco-Rotea, 2015: 149-150).
} 
sistema defensivo do río Miño, que formaría parte dun sistema defensivo máis complexo que engloba toda a fronteira hispano-portuguesa. Con todo, a zona que nos ocupa presenta as súas propias características, motivadas pola presenza do río Miño, a configuración xeográfica do val e a articulación histórica das poboacións da fronteira, situadas onde se localizan os pasos de barca.

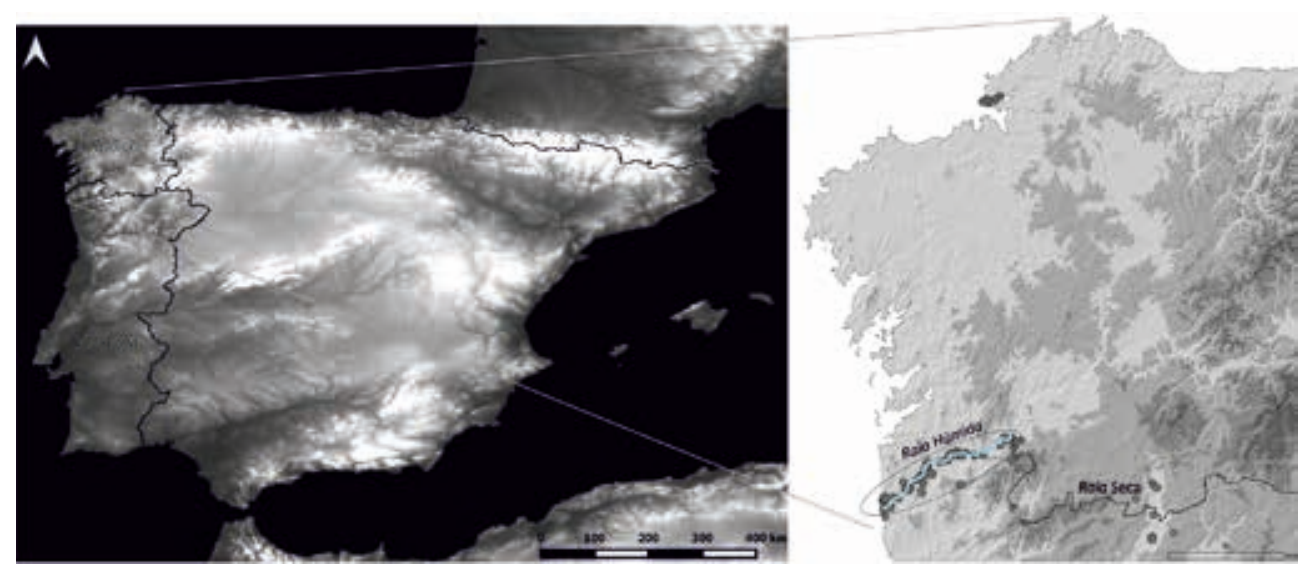

Figura 4. Localización da zona analizada neste texto. Á esquerda, mapa da Península Ibérica (STRM 90 CGIAR-CSI, elaborado por José Costa), no que se destacan Portugal e Galicia. Á dereita, mapa de Galicia coa diferenciación da fronteira galaico-portuguesa; marcouse a zona miñota en azul

En concreto, a paisaxe fortificada miñota confórmase como a suma de oito conxuntos defensivos (figura 5) que aglutinan unha serie de fortificacións, vías de tránsito, pasos de barcas e estruturas de control do territorio, e do espazo físico cruzado polo río Miño. Este río é un elemento transversal á paisaxe analizada co que se relacionan todos os conxuntos ou subsistemas de forma directa excepto o de Extremo (Arcos de Valdevez), situado entre as serras da Boulhosa e da Peneda, que se relaciona con eles de forma indirecta 9 . A maior parte dos conxuntos articúlanse con base en dúas poboacións enfrontadas, situadas en ambas as marxes

9 Esta configuración resulta do estudo realizado pola autora con motivo do desenvolvemento da súa tese de doutoramento. Hoxe en día, grazas aos traballos desenvolvidos a través dunha Axuda de apoio á etapa de formación posdoutoral do Sistema de I+D+i galego (Modalidade A, Convocatoria 2016), dentro do Grupo de Investigación Síncrisis da USC, sabemos que este sistema é mais complexo aínda e que, no caso de Extremo, existe un maior número de elementos que forman parte deste subsistema e que posibilitan esta interconexión con outros subsistemas e co propio río Miño. 
do río. Ademais, localízanse en nós viarios, en relación coa vía fluvial que supón o Miño, as vías terrestres que discorren paralelas a este e os pasos de barca, pero tamén as vías terrestres perpendiculares ao Miño que o comunican co interior dos respectivos países, coma no caso do conxunto de Extremo.

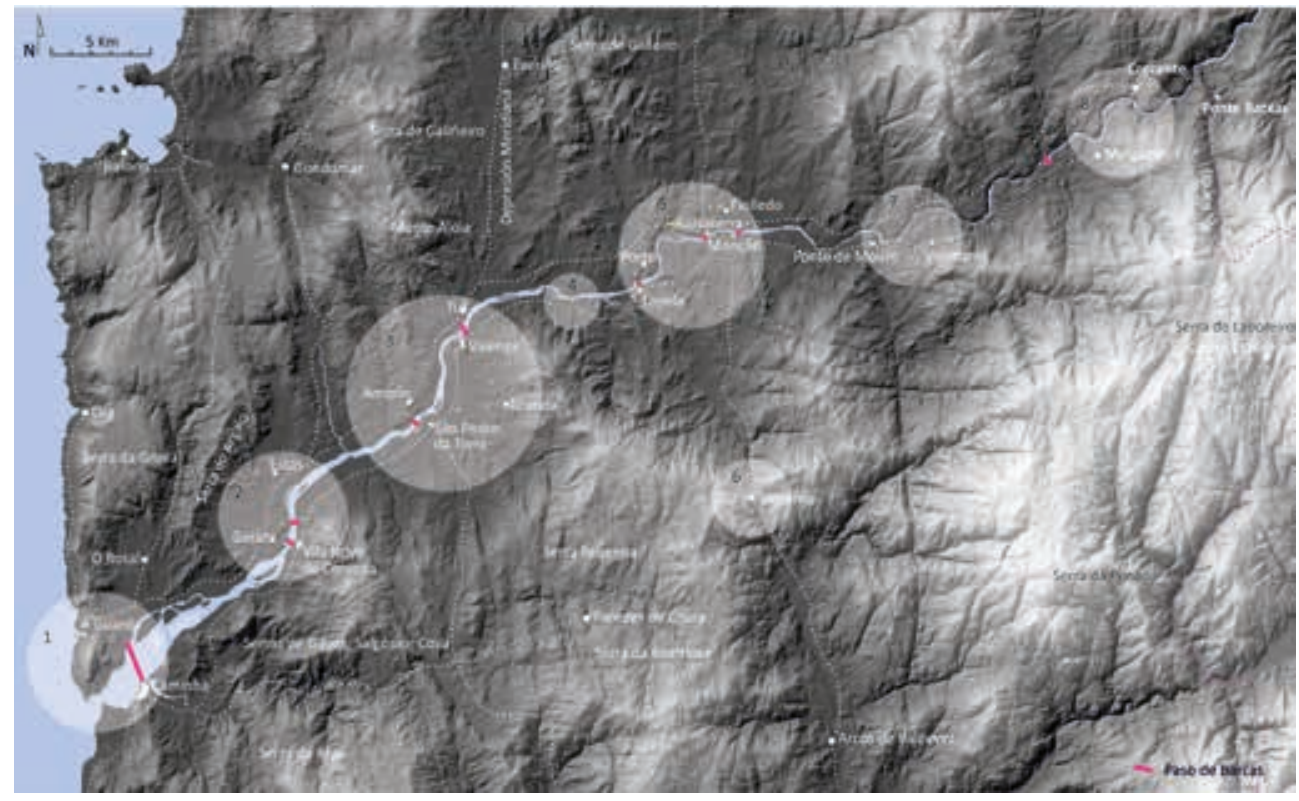

Figura 5. MDE da fronteira miñota ou Raia Húmida. Nesta imaxe, pódese observar a estrutura do territorio, percorrido polo río Miño de nordeste a suroeste formando unha planicie aluvial en ambas as dúas marxes pechada polas cadeas montañosas polo norte e o sur. En liña de puntos de cor branco, marcáronse as principais vías de tránsito terrestres. En maxenta, os pasos de barcas. Dentro dos círculos, sitúanse os subsistemas identificados: 1. Subsistema A Guarda-A Ínsua-Caminha; 2. Subsistema Goián-Vila Nova de Cerveira-Estás; 3. Subsistema Amorín-Tui-São Pedro da Torre-Valença; 4. Subsistema de Verdoejo; 5. Subsistema Salvaterra de Miño-Monção; 6. Subsistema de Extremo; 7. Subsistema de Ponte de Mouro-Valadares; 8. Subsistema Melgaço-Crecente

Cada subsistema, pola súa vez, relaciónase coa unidade territorial na que se sitúa. Na figura 6 , podemos observar a cunca fisiográfica na que se localizan as poboacións de Goián, Vila Nova de Cerveira e Estás, pechada ao norte pola serra do Argalo e ao leste-suroeste polas serras de Gávea, Salgosa e Cova, de xeito que o conxunto que conforman as fortificacións das poboacións e as súas contornas se sitúa de tal maneira que controla todo este espazo. Por outra parte, os conxuntos manteñen unha relación visual e espacial co conxunto precedente e o seguinte 
mediante fachos ou pequenos postos de vixilancia situados en altura, de forma que o control do territorio se estende á totalidade da paisaxe.

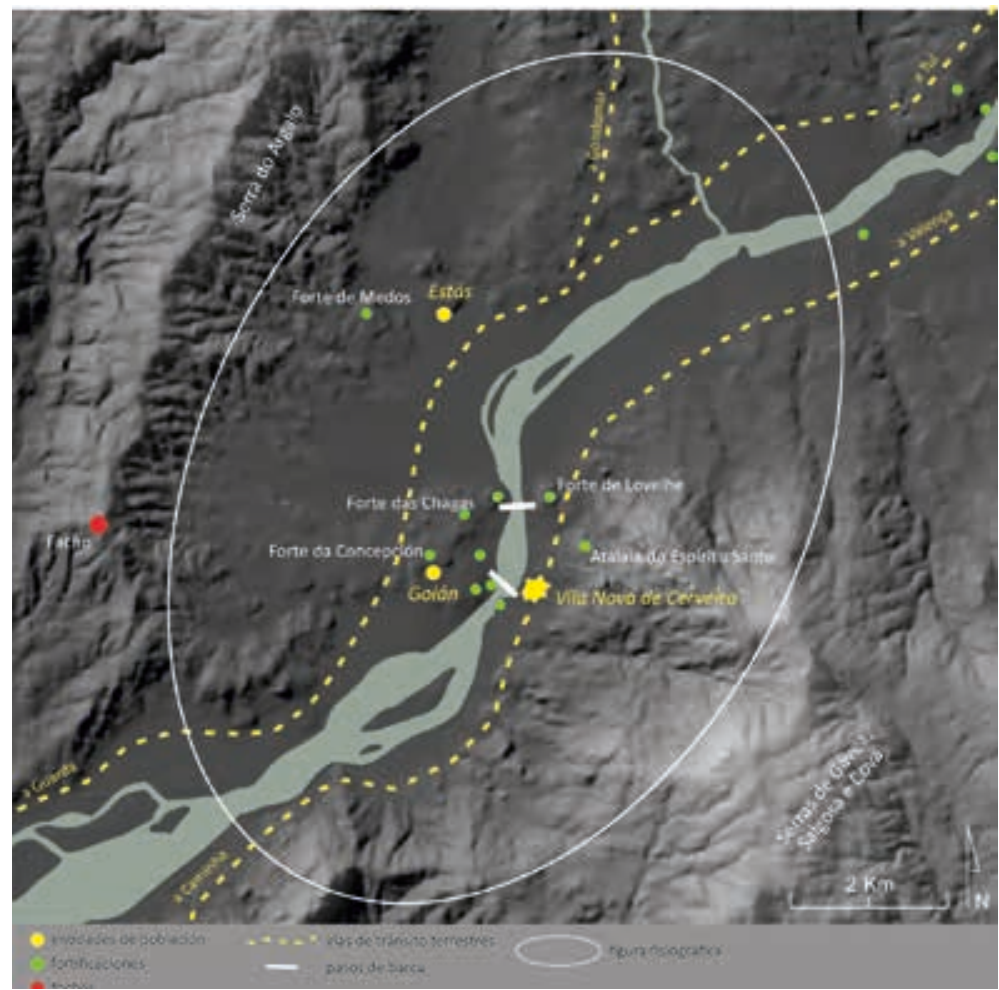

Figura 6. MDE da zona na que se localiza o subsistema Goián-Vila Nova de Cerveira-Estás. O facho situado na serra do Argalo permite comunicar visualmente este sistema e o da Guarda-A Ínsua-Caminha, situado ao OSO. As poboacións de Goián e Vila Nova de Cerveira sitúanse nunha zona de paso, tanto terrestre coma fluvial

En definitiva, os aspectos que caracterizan a paisaxe defensiva miñota son:

- $\mathrm{Na}$ fronteira galego-portuguesa conviven dous modelos de fortificación, un medieval e outro de época moderna, que se conservan de maneira moi diferente nos distintos espazos analizados, sobre todo os núcleos urbanos.

- Os conxuntos defensivos modernos situados na Raia organízanse arredor dunha poboación principal localizada a cada lado da fronteira que adoita ter unha estrutura urbana encerrada, envolta e protexida por un sistema defensivo. 
- Existen outros conxuntos que defenden as vías de comunicación que enlazan os espazos de fronteira co interior de cada un dos países que forman parte do sistema defensivo global.

- Todos estes conxuntos forman parte dun sistema defensivo moi complexo que aínda non coñecemos na súa totalidade e que se foi construíndo a medida que avanzaba a Guerra da Restauração.

\section{A POSTA EN VALOR DA PAISAXE FORTIFICADA MODERNA DO RÍO MIÑO}

As xornadas "A posta en valor do patrimonio cultural dos ríos: Galicia e outros exemplos», organizadas polo Consello da Cultura Galega, tiñan un dobre obxectivo: por unha parte, pór a mirada sobre o patrimonio cultural que está asociado aos ríos e, por outra, recoller unha lectura ecolóxica do territorio a partir dos espazos naturais e a súa conexión por corredores fluviais e infraestruturas verdes, que introduciu unha nova dimensión precisamente a ese patrimonio cultural dos ríos, onde se veñen levando a cabo interesantes experiencias necesarias para a protección e rehabilitación deste patrimonio cultural, e que contribúen á súa posta en valor desde distintas iniciativas. Precisamente, o caso do estudo da paisaxe defensiva do Miño fronteirizo, dos elementos que integran esa paisaxe e da súa interrelación co patrimonio constitúen unha destas experiencias levadas a cabo, neste caso nun espazo internacional. Para mostrar os principios desta posta en valor no caso que nos ocupa, por unha parte, empregamos o concepto de Cadea de Valor do Patrimonio Cultural (en diante, CVPC), por outra, partimos de tres preguntas.

\section{A CADEA DE VALOR DO PATRIMONIO CULTURAL APLICADA Á PAISAXE FORTIFICADA MODERNA DO RÍO MIÑO}

A Cadea de Valor do Patrimonio Cultural aplicada á arqueoloxía foi desenvolvida inicialmente por Felipe Criado-Boado (Criado-Boado, 1996a: 27-30 e 1996b) baixo o concepto de cadea interpretativa e recollida posteriormente por Matilde González Méndez na súa tese de doutoramento (González, 1999: 17-23). 
Será posteriormente cando se lle outorgue esta nova denominación como CVPC (Amado, Barreiro, Criado-Boado e Martínez López, 2002) porque se considera que «é máis acertado o concepto de cadea valorativa ou cadea de valor porque no proceso [...] entran en xogo diferentes estratexias para a produción de coñecemento, non só a interpretación» (Barreiro, 2009: 10).

A aplicación da CVPC xorde ante a necesidade de deseñar unha estratexia de revalorización do patrimonio que tome posicións «a favor da súa conversión nun recurso para o desenvolvemento económico e cultural» (Barreiro, 2009: 10) sen perder os valores que durante o proceso de revalorización se van engadindo sobre o patrimonio e van evitando que se «cousifique».

Articúlase nunha serie de fases ou instancias valorativas que constitúen os distintos elos da cadea: identificación, documentación, significación, valoración, conservación, posta en valor e recepción (figura 7). En cada unha destas instancias valorativas, aplícanse distintas estratexias de produción de coñecemento que van xerando un efecto de incremento na seguinte instancia e un valor engadido (Barreiro, 2009: 10). Este proceso de revalorización aplicado de forma sistemática fai que, en todas as fases da cadea, incluso nas últimas que implican a reversión social do patrimonio, os bens manteñan todos os seus valores.

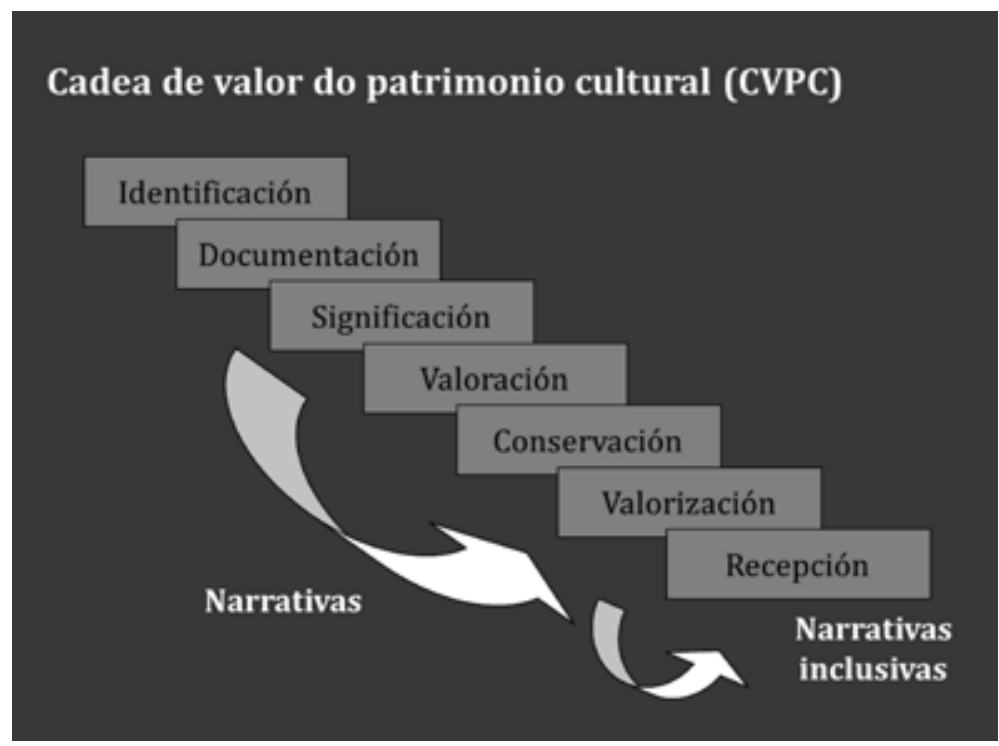

Figura 7. Representación das distintas instancias da CVPC (fonte orixinal: Felipe Criado-Boado) 
Poderiamos dicir que a CVPC consta de tres grandes fases nas que se aglutinan estas instancias: a valoración, a avaliación e a revalorización (Criado-Boado, 1996b: 76-77). A primeira delas é a práctica interpretativa que intenta estimar o valor orixinal dun elemento histórico; é unha práctica teórica que xera unha representación do modelo descritivo e interpretativo sobre unha entidade ou grupo de entidades (Criado-Boado, 1996b: 76). No caso das entidades arqueolóxicas, unha valoración arqueolóxica é dúas cousas ao mesmo tempo: unha reconstrución do valor orixinal e un recoñecemento do seu valor actual. A segunda, a avaliación ou valoración patrimonial, é a práctica interpretativa que intenta calcular o valor patrimonial dun elemento histórico desde un punto de vista patrimonial; é unha práctica teórica que xera un modelo de xestión, protección e/ou revalorización da entidade ou grupo de entidades analizados. Converte o documento histórico en patrimonio histórico, a entidade arqueolóxica en patrimonio arqueolóxico (Criado-Boado, 1996b: 76). Finalmente, a revalorización é unha práctica interpretativa que converte o patrimonio histórico en bens; constitúe unha práctica teórica que xera unha alternativa que posibilita unha rendibilidade sociocultural dese elemento. Os seus resultados poden ser de tipo material (unha actuación física sobre un obxecto) e inmaterial (un argumento que dote de sentido un obxecto) (Criado-Boado, 1996b: 76-77). En relación con estes resultados, Criado-Boado diferencia dous tipos distintos de prácticas de revalorización: a rendibilidade, que sería a forma de revalorizar un elemento arqueolóxico a través dunha acción intanxible dotando meramente ese elemento dun argumento (no noso caso, a construción dun discurso histórico a través da valorización dos elementos que forman parte da paisaxe fortificada da Raia miñota, e que recupere a súa memoria esquecida), e a rehabilitación, que sería a acción física sobre el (unha vez valorizados e avaliados os bens, serán revalorizados mediante unha acción que os recupere fisicamente, por exemplo mediante a limpeza, escavación e restauración deses mesmos bens). 


\section{TRES PREGUNTAS}

\section{Canto tempo é necesario para que perdamos a memoria histórica do noso patrimonio?}

Cando comezamos a traballar no ano 2003 no contexto da redacción do plan director (en diante, PD) FORTRANS (Cobos e Hoyuela, 2005; Vecoña, 2006) na zona do Baixo Miño, a situación do forte de Santa Cruz, na vila da Guarda, era a que reflicte a imaxe que mostramos na figura 8 , un elemento practicamente oculto aos ollos da veciñanza, cuberto de árbores, no que se comezaba a rozar o exterior do cuadrante O-N-E con motivo dun plan urbanístico aprobado na súa contorna. Resultaba de especial interese para o noso proxecto descubrir para os que eramos foráneos da vila a presenza dunha fortificación que fora practicamente invisibilizada e eliminada da memoria de moitos veciños e veciñas, e que, non obstante, era unha das de maior envergadura deste lado da fronteira, de carácter permanente (realizado en pedra) e nun estado de conservación en bastante mellor situación ca noutros casos analizados.

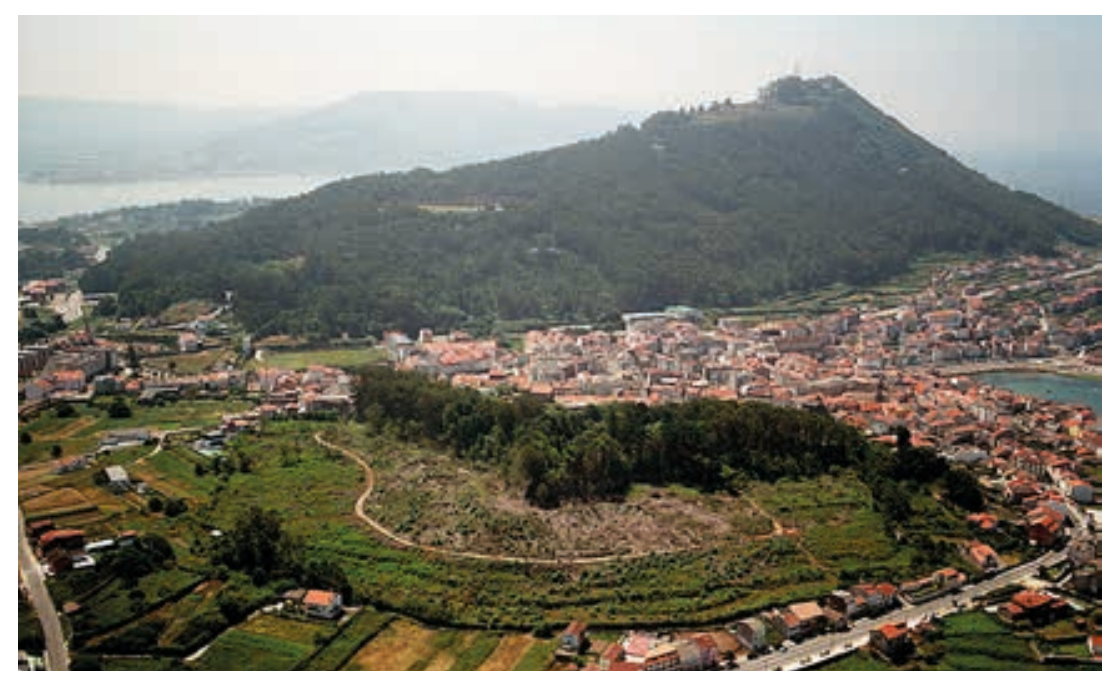

Figura 8. Vista aérea da vila da Guarda (Fonte: Paisajes Españoles S. A., 2001). Na parte central da imaxe, nun pequeno outeiro que domina a vila construída ao redor dunha pequena enseada, localízase o forte de Santa Cruz ${ }^{10}$

${ }^{10}$ Coñecido popularmente como castelo de Santa Cruz. 
Porén, a imaxe que existía dela a través das fotografías históricas que conservaba, entre outros, o veciño Antonio Martínez Vicente, perdérase na memoria en menos dun século, cando, a partir da venda por parcelas do forte de Santa Cruz a distintos propietarios en 1860, se inicia a súa transformación: un dos novos donos, Ángel González Sobrino, restaura as murallas e destina parte do recinto a recreo e cultivo; tamén se construirá, pegada á súa muralla polo exterior, unha fábrica de embutidos e, no interior, a fábrica de cerámica Santa Cruz, provedora da Casa Real, propiedade de D. Juan A. Lomba Álvarez (Garrido, 2004).

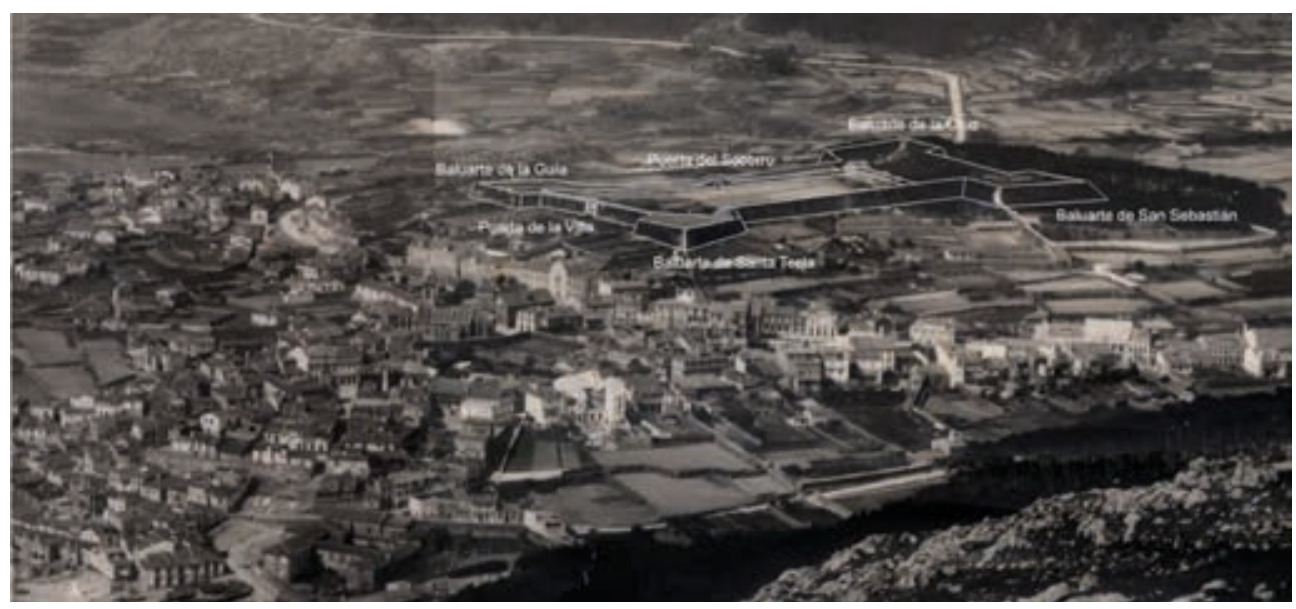

Figura 9. Forte de Santa Cruz na primeira metade do século xx (fotografía propiedade de Antonio Martínez Vicente). Nela, debuxamos o volume do forte e indicamos as súas partes principais

Como resultado desta transformación, engadíronse ao longo das seguintes décadas unha serie de predios particulares na fronte suroeste que ocultaban parte do perímetro do forte. Unicamente o acceso á Porta da Vila, principal entrada á fortificación, se respectou deixando un camiño que discorre entre predios particulares e os seus muros de peche. $\mathrm{O}$ mesmo sucedeu na súa fronte sueste, ocupada por grandes predios particulares. Os muros que as delimitan morren, respectivamente, no ángulo capital dos baluartes de Santa Trega e San Sebastián. O seu interior foi ocupado por unha gran cantidade de vexetación arbustiva que oculta este fronte á vista. O mesmo fenómeno sucedeu no interior do castelo, onde tamén se desenvolvera un frondoso xardín con abundante vexetación e se construíran varias estruturas. Todos estes elementos facían que esta peza da fortifi- 
cación abaluartada fronteiriza fose pouco a pouco ocultándose no pasado recente da vila até chegar a invisibilizarse na súa memoria. Ese proceso, en certo modo, foi revertido cos traballos vencellados á redacción do PD (figura 9).
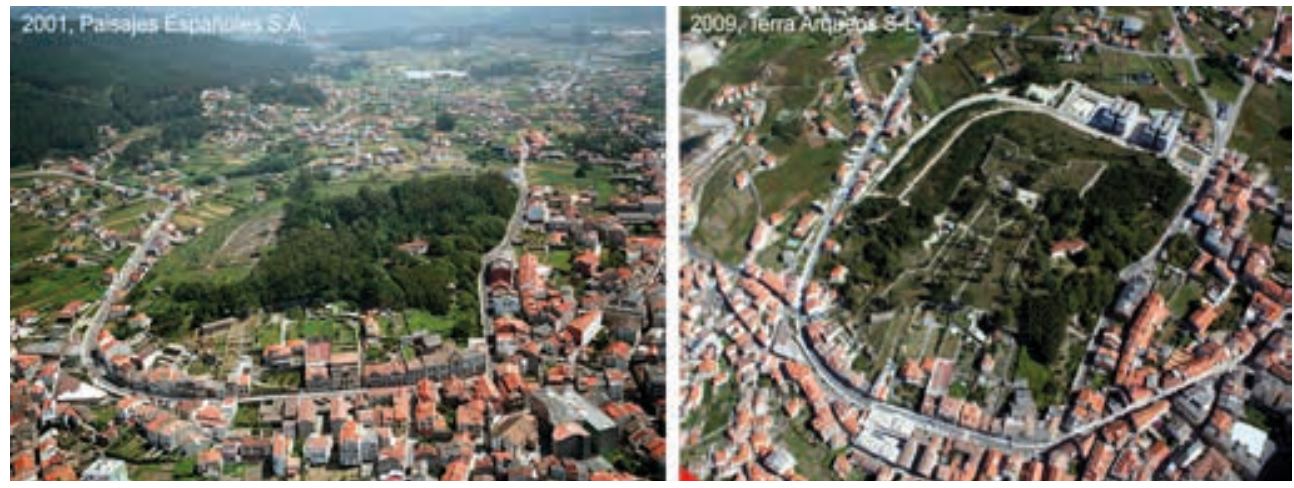

Figura 10. Nos últimos anos, levouse a cabo un proxecto de recuperación do forte que incluía a adquisición por parte das administracións públicas, a corta da vexetación interior e exterior, a restauración dos elementos construtivos e a recuperación dunha das edificacións interiores como lugar expositivo. Porén, xorde tamén un novo proceso de invisibilización parcial da fortaleza a raíz da urbanización da súa contorna. Na imaxe da dereita, pódense ver as torres construídas

Cando comezou o desenvolvemento do PD FORTRANS, existía, como comentamos, un plan urbanístico xa aprobado para a contorna do forte, que suporía a súa urbanización coa construción de pistas e varios edificios de vivenda de gran porte sobre a súa explanada exterior, elemento que forma parte del e ten un papel fundamental para a súa comprensión. A pesar dos resultados dos estudos previos, este plan seguiu adiante. Hoxe levouse a cabo parcialmente e construíronse dúas das torres de vivendas proxectadas, o que motivou unha nova invisibilización parcial do castelo, que, en función da localización da persoa que o mira, pode quedar totalmente oculto se observamos, por exemplo, A Guarda desde o río Miño ou cando se accede á vila desde o nordeste (figura 9).

\section{Como podemos recuperar esa memoria?}

O traballo arqueolóxico realizado, primeiro, no contexto do estudo do PD FORTRANS (Blanco-Rotea, 2009) e, logo, na elaboración da tese de doutoramento da autora (Blanco-Rotea, 2015) está baseado no emprego da CVPC como ferramenta hermenéutica. Desde ela, preténdese converter o patrimonio 
arqueolóxico nun recurso para o desenvolvemento económico e cultural, pero antes haberá que dotalo de contido, sendo tres, como vimos, as grandes fases para conseguilo: a valoración do ben (proceso de identificación, documentación, significación e valoración dos bens que integran a paisaxe fortificada miñota), a avaliación (proceso de conservación e valoración desa paisaxe) e a revalorización (proceso de posta en valor e recepción desa paisaxe). Para desenvolver estas fases, deseñamos un método de traballo que pasa por analizar as paisaxes nas súas distintas escalas de significación (microespacial, semi-microespacial e macroespacial), intentando identificar, documentar e comprender a materialidade e, con ela, os valores que están detrás de cada un dos elementos que durante a Guerra da Restauração portuguesa se construíron no territorio miñoto, como fortalezas, plataformas, baterías, atalaias, fachos, pasos de barcas, vías... (escala microespacial); as relacións que estes elementos gardan entre si formando conxuntos defensivos ou subsistemas (escala semi-microespacial), e, finalmente, as relacións entre estes e o territorio, o que deu lugar a unha paisaxe fortificada complexa (escala macroespacial). Así, podiamos reconstruír aquela paisaxe esquecida, valorizala e logo socializala mediante mecanismos que integrasen as comunidades locais.

Aínda que xa temos comentado esa metodoloxía en traballos anteriores (Blanco-Rotea, 2008, 2011a, 2018), expoñemos aquí os seus pasos principais ${ }^{11}$ :

- Estudo das fontes documentais e bibliográficas.

- Análise de documentos gráficos e superposición destes documentos sobre fotografías aéreas e satélite actuais.

- Identificación de elementos fortificados:

- Prospección aérea mediante fotointerpretación e análises de datos LiDAR (Light Detection and Ranging) (Jones, 2010).

- Prospección arqueolóxica dos cascos históricos e as súas contornas (Blanco-Rotea, 2011a: 187-190), así como das marxes do río Miño, especialmente nas zonas onde se localizaban os pasos de barca históricos.

- Caracterización dos elementos fortificados:

○ No caso dos espazos urbanos e das fortificacións permanentes:

11 Se se quere revisar a súa aplicación a unha paisaxe fortificada urbana, véxase Blanco-Rotea, 2018, concretamente a figura 4 , onde se mostra o proceso de análise da paisaxe urbana fortificada da cidade de Tui. 
- Análise de corpos de fábrica (Quirós e Gobbato, 2004: 193): diferenciación de grandes volumes con homoxeneidade funcional e estratigráfica.

- Lectura das fábricas (Caballero, 1995): diferenciación de fases construtivas.

- No caso dos espazos non urbanos e das fortificacións de campaña:

- Análise formal dos elementos identificados.

- Definición e caracterización da planta.

- Xeorreferenciación dos datos no Google Earth e baleirado nun SIX (sistema de información xeográfica) (Lock e Stancic, 1995).

- Construción dos MDE (modelos dixitais de elevacións) (Wheatley e Gillings, 1999).

- Análise de visibilidade (Wheatley, 1995) e de mobilidade (Llobera, Fábrega-Álvarez e Parcero-Oubiña, 2011).

- Caracterización da paisaxe (sistema).

- Clasificación dos elementos que compoñen a paisaxe (subsistemas).

- Construción de modelos teóricos.

- Procesos de posta en valor da paisaxe e dos elementos que a integran.

- Análise da recepción desta paisaxe por parte das comunidades locais.

\section{Por que é importante recuperar esa memoria e, con ela, o patrimonio?}

Reflexión sobre as consecuencias da perda dese patrimonio. Seguindo a matriz empregada por Criado-Boado que representa a ontoloxía do patrimonio arqueolóxico (en diante, PA) (Criado-Boado, 2012: 193-194), este represéntase con tres dimensións: como documento (do pasado), como obxecto (do pasado no presente) e como recurso (no presente). Neste último caso, no que o PA está composto por obxectos e documentos, temos a obriga de estudalo e xestionalo no presente. Isto é extensible a calquera elemento que forme parte dese PA, especialmente no caso da arquitectura, onde a súa conservación e mantemento está ligada ao seu uso. $\mathrm{O}$ uso que lle deamos a esta arquitectura dependerá de moitos factores; en primeiro lugar, das políticas patrimoniais, pero tamén do seu réxime de propiedade, do seu estado de conservación e, ante todo, do seu recoñecemento social. O PA que non se coñece e non se valora socialmente dificilmente pode ser estudado, conservado e usado. 


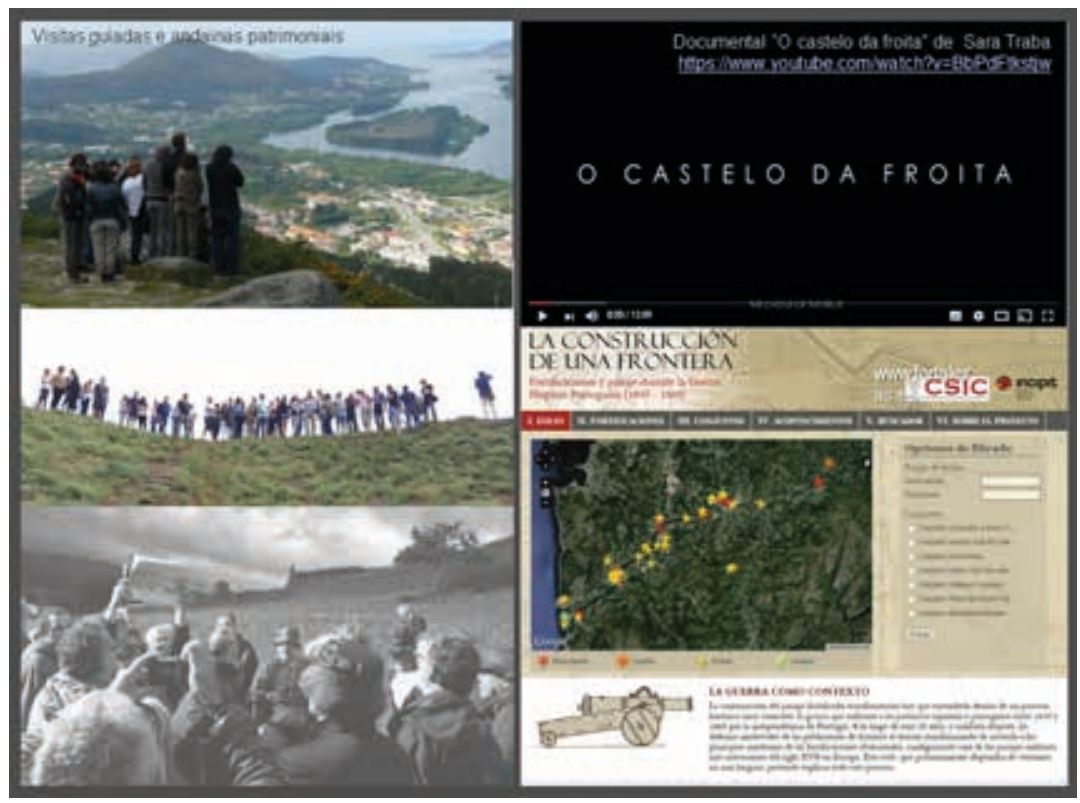

Figura 11. Estratexia 1: pór en valor o patrimonio. No proceso de recuperación da memoria desta paisaxe o relato foise dotando de contido e comezou un proceso de reencontro con estes espazos, de posta en valor que abrangueu distintas accións

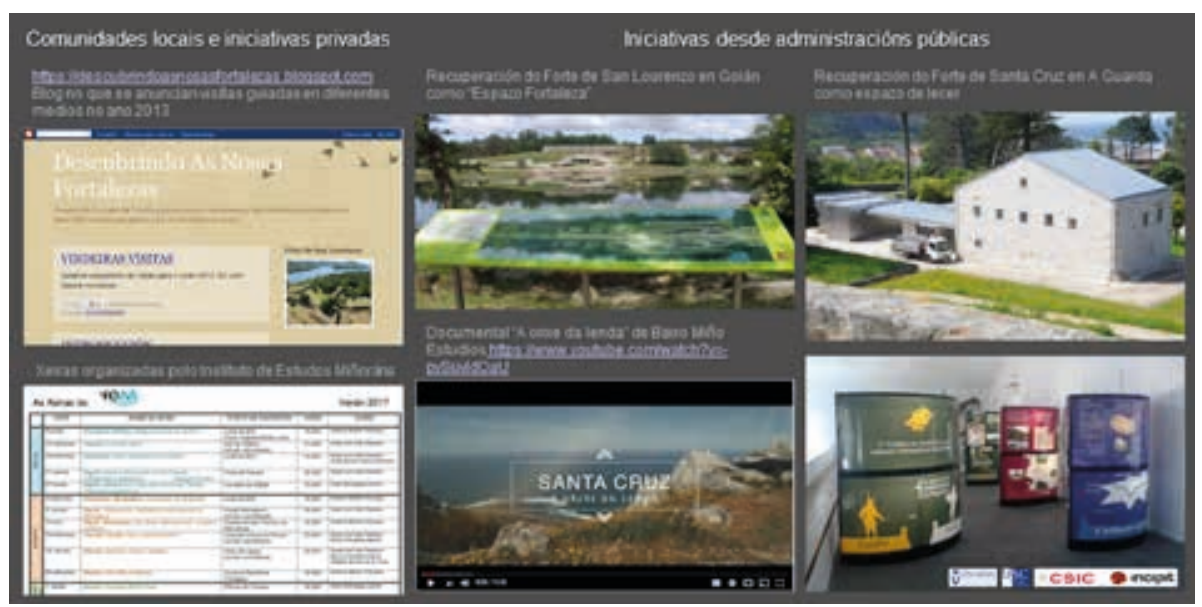

Figura 12. Estratexia 2: converter o patrimonio nun recurso cultural. Xa con posterioridade, leváronse a cabo diferentes iniciativas por parte tanto de particulares coma de asociacións locais ou de administracións públicas, encamiñadas a dotar esta paisaxe e os seus elementos nun recurso cultural. Este aspecto aínda está por acabar de ser definido e de «explotar», patrimonialmente falando, en toda a Raia Húmida. Porén, para chegar até aquí, era necesario desenvolver todos as fases da CVPC 


\section{MATERIALIDADES E PATRIMONIOS}

Durante o proceso de análise de toda esta paisaxe identificouse unha serie de materialidades de natureza homoxénea, mais todas elas parecían ter unha relación entre si que podiamos identificar a través das propias crónicas e fontes históricas que narraban os feitos da guerra (i. e., Ávila y La Cueva, 1895; Ericeira, 1945, ou Gándara, 1677) e como, no seu devir, se ían modernizando as defensas medievais das vilas e cidades da Raia ou se construían novas fortificacións nas súas contornas para protexer a poboación dos ataques do exército inimigo con novas armas de fogo para as que as torres e os castelos medievais non estaban preparados mentres non se remataban as novas defensas. Identificar estas materialidades, caracterizalas e valorizalas foi o proceso que levou a converter cada un destes elementos e o conxunto que conforman, a paisaxe fortificada miñota, en patrimonio.

Actualmente, dous son os conxuntos defensivos nos que se levou a cabo unha maior actividade encamiñada á súa posta en valor, coa importante (pero irregular e insuficiente) intervención por parte das administracións públicas na recuperación dos seus espazos, tal e como recollemos na figura 12. Para ilustrar apenas unha parte desta materialidade, retomamos a figura 6 , onde se mostra un dos conxuntos defensivos analizados na Raia, o de Goián-Vila Nova de Cerveira-Medos.

As fortificacións que compoñen este sistema son, en Portugal, a Praça Forte de Vila Nova de Cerveira, os fortes de Lovelhe e de São Francisco, e a batería da Mata ou Atalaia do Espírito Santo. En Galicia, estarían, en Goián, o forte da Barca, a fortaleza de Nosa Sra. da Concepción, o forte das Chagas, a torre dos Ratos e a torre dos Correa e, en Estás, o castelo de Medos e forte de Santiago Carrillo.

Existían tanto no lugar da Barca coma en Vila Nova unha poboación en época medieval. No caso da Barca, estaba defendida por unha pequena torre. Tras as primeiras incursións na vila en 1643 por parte dos portugueses, levántanse unhas trincheiras no lugar da Barca, no porto, e constrúese un pequeno forte de catro baluartes «que rodeabam uma torre antiga» (Ericeira, 1945, vol. IV: 170) en 1644 denominado forte da Barca. 

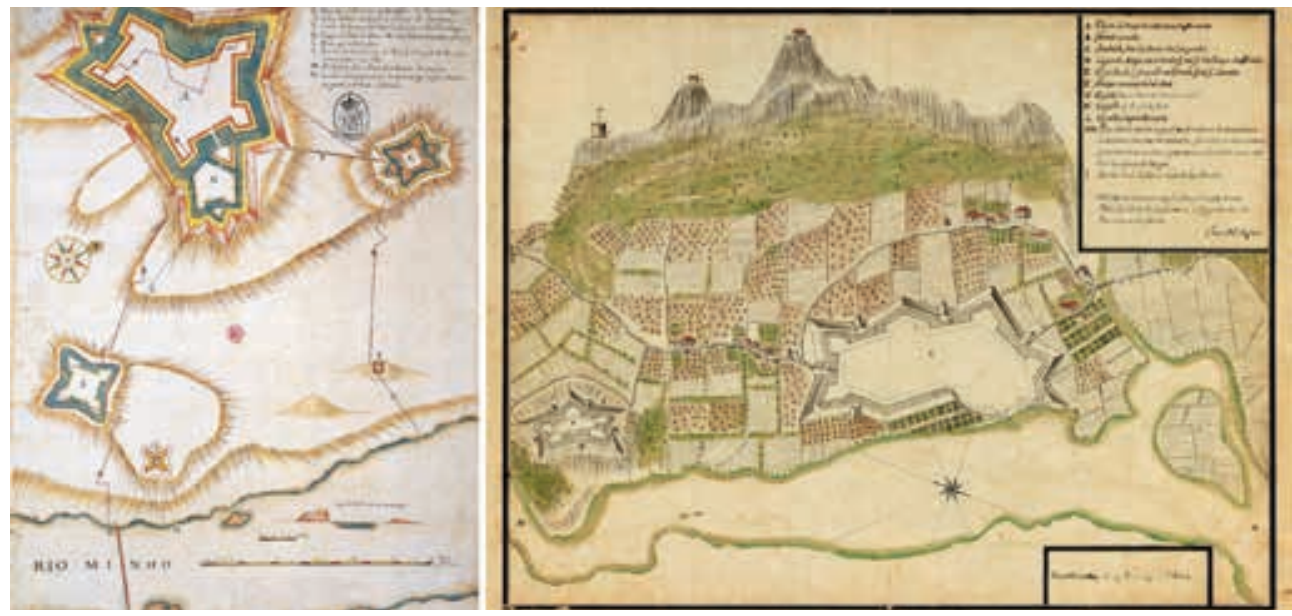

Figura 13. Á esquerda, plano histórico da fortaleza de Nosa Sra. da Concepción, en Goián, e as fortificacións que a rodean, ademais das trincheiras que as unen. Está atribuído por Garrido a Miguel de Lescol (aprox. 1664) (Garrido, 2004: 17) ${ }^{12}$. Á dereita, planta de Vila Nova de Cerveira e fortificacións próximas de Joze Miz.s da Cruz (1759) (GEAM 2145, Lisboa, copia no Arquivo privado de Jaime Garrido)

No lugar de Vila Nova (anteriormente, Cerveira) existía un castelo polo menos desde o século XIII que aínda se conserva, mais que foi obxecto dalgunhas reformas posteriores. Ten unha planta ovalada rodeada dunha muralla con varias torres cuadrangulares no seu perímetro (figura 14). Contaba con dúas portas, unha ao leste, denominada Porta da Vila, e outra ao oeste, cara ao río, denominada Porta da Traição. En 1320, pasa a denominarse Vila Nova de Cerveira cando D. Dinis lle outorga a Carta Foral. A barbacá constrúese nos séculos XIV e XV. Existen ademais referencias a outras reformas nas defensas tanto no século XV coma no XVI. En 1641, o gobernador de armas de Entre Douro e Minho mandou atrincheirar a vila.

${ }^{12}$ Existen informacións contraditorias sobre este plano conservado na Biblioteca Nacional de Lisboa (http:// purl.pt/25504). O plano non está datado nin firmado, pero na ficha correspondente da Biblioteca Nacional de Portugal atribúese a Manuel Pinto de Vilalobos e dátase en 1713. Se analizamos en detalle o plano e o comparamos con outros do mesmo autor realizados entón, veremos que difiren a grafía, a forma de representar as fortificacións, os trazos da topografía ou as cores. Por outra parte, con respecto ao forte de San Lourenzo, no plano especifícase o seguinte: «Forte que se ha de facer». Este forte iníciase en 1672 e remátase 1673, como sabemos, polo que en 1713 xa debería estar construído. Pola contra, Jaime Garrido considera que foi elaborado por Miguel de Lescol arredor de 1664, quen estaba traballando nesa data nas fortificacións portuguesas da fronteira do Minho ás ordes do conde de Prado (Garrido, 2004: 17). Nós, tendo en conta as diferenzas cos planos de Vilalobos e a data de construción do forte de San Lourenzo, decantámonos pola hipótese de Garrido. 


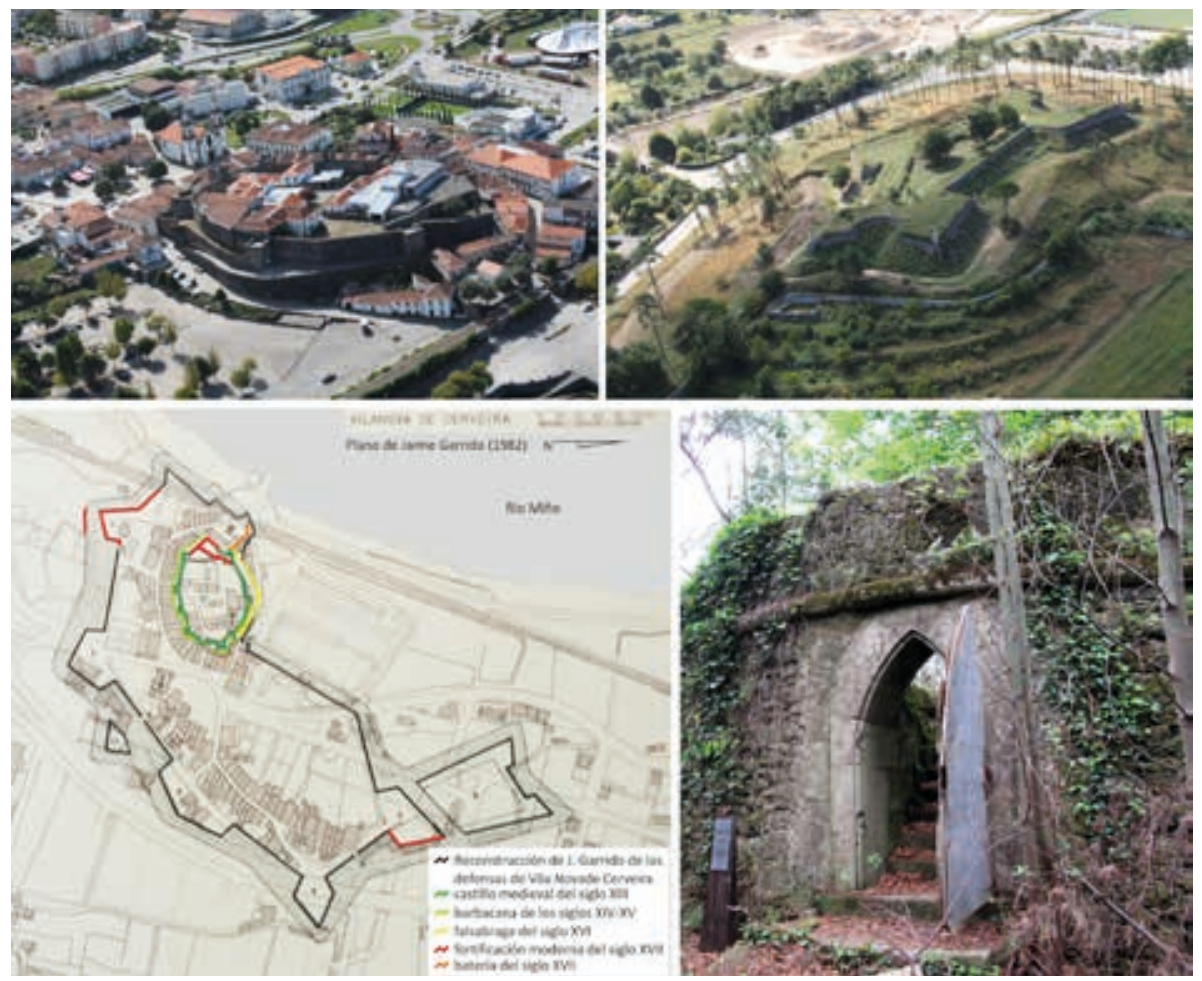

Figura 14. Arriba, vistas aéreas do castelo de Vila Nova de Cerveira (esquerda) e do forte de Lovelhe de 2009 (dereita) (proporcionadas por Terra Arqueos S. L.). Abaixo, á dereita, fotografía da porta de acceso á Atalaia do Espírito Santo do 2009; á esquerda, plano coa delimitación das estruturas fortificadas conservadas en Vila Nova de Cerveira

A actividade construtora comeza de maneira máis intensa no lado portugués, xa que será necesaria como apoio loxístico á toma da súa veciña A Barca. En 1642, comézase o forte de São Francisco, situado na poboación de Lovelhe, a $1 \mathrm{~km}$ ao norte de Vila Nova nunha eminencia desde a que se domina esta vila e o lugar da Barca. Non se concluirá até 1663 , pero en «1643 asiste ao asedio das tropas galegas a Vila Nova, mais aínda estaba ao inicio dos traballos» (CADIVAFOR, 2008: 141). Trátase dun forte de planta pentagonal con cinco baluartes, tres cortinas, foso, camiño cuberto e unha única porta polo sueste. É unha obra permanente coas defensas exteriores de terra. Actualmente, é un dos fortes que mellor se conservan na zona (figura 14). 
Descoñecemos o momento de construción da Atalaia do Espírito Santo (figura 14), pero as súas características tipolóxicas e construtivas responden ao tipo de fortificación que nos ocupa. Esta batería localízase no último chanzo cara ao río Miño da serra da Gávea, que, xunto coas de Salgosa e Coba, forman un arco que rodea a rexión de Vila Nova de Cerveira achegándose case até o río Miño. Nun alto, dominando Lovelhe, Vila Nova e Goián, disponse un pequeno reduto de planta rectangular, coas esquinas moi saíntes pero sen chegaren a formar baluartes, realizado en cachotaría irregular. Está rodeado dun foso cortado na rocha e sobre o reduto consérvase unha torre de planta circular con catro troneiras na parte superior. As representacións que se conservan dela son de planos xerais (Blanco-Rotea, 2015: 475-478). Desde este posto controlaba, ademais das poboacións xa comentadas, o paso cara ao seguinte subsistema de Valença-Tui.

Existiu tamén un proxecto para a construción dun pequeno fortín nun illote situado ao suroeste de Vila Nova, enfrontado ao forte de San Lourenzo (e antes ao forte da Barca), pero non conservamos evidencias da súa construción (Blanco-Rotea, 2015: 469-471).

A fortaleza moderna de Vila Nova de Cerveira levantouse entre 1660 e 1667 segundo o proxecto de Francisco de Acevedo. A súa construción abordouse en paralelo coa da Nosa Sra. da Concepción, en Goián. A praza envolveu o castelo medieval e o casarío que se fora construíndo extra muros polo sur, o leste e o norte. Contaba con catro baluartes, dous semi-baluartes e tres redutos virados ao río, e estaba rodeado dun foso. Ademais, na zona norte tiña un hornaveque e un revelín protexendo unha das cortinas ao leste (pódese ver a planta na figura 13). Actualmente consérvanse apenas restos deste trazado moderno, como se pode ver na figura 14.

Xa no lado galego, a excepción do forte da Barca, toda a defensa se constrúe a partir da toma do lugar polos portugueses en 1663 e é de autoría lusa (figura 15). En primeiro lugar, levántase, nunha eminencia ao NNO do forte da Barca a Fortaleza de Nosa Sra. da Concepción, un forte terreiro de grandes dimensións, de planta irregular con cinco baluartes e un hornaveque con dous semi-baluartes cara ao leste. Na gola do hornaveque localizábase un revelín que protexía o acceso ao recinto (Blanco-Rotea, 2015: 332-338). Iniciouse en 1663 e pronto se rematou. Aínda que os planos que se conservan da fortificación non están firmados (figura 13), algúns autores consideran que a súa autoría é do enxeñeiro Manuel 
Pintos de Villalobos (http://www.cieform.org/detalle.cis?id=10, consulta de xuño de 2010) mentres que outros lla atribúen a Miguel de Lescol (Garrido, 2004: 17). A fortaleza atópase moi arrasada, tanto pola afección do crecemento urbano, coma pola concentración parcelaria, a construción dunha posta e unha areeira, a repoboación etc., xa no remate da guerra foi destruída parcialmente cando se devolveron as prazas ao país contrario.

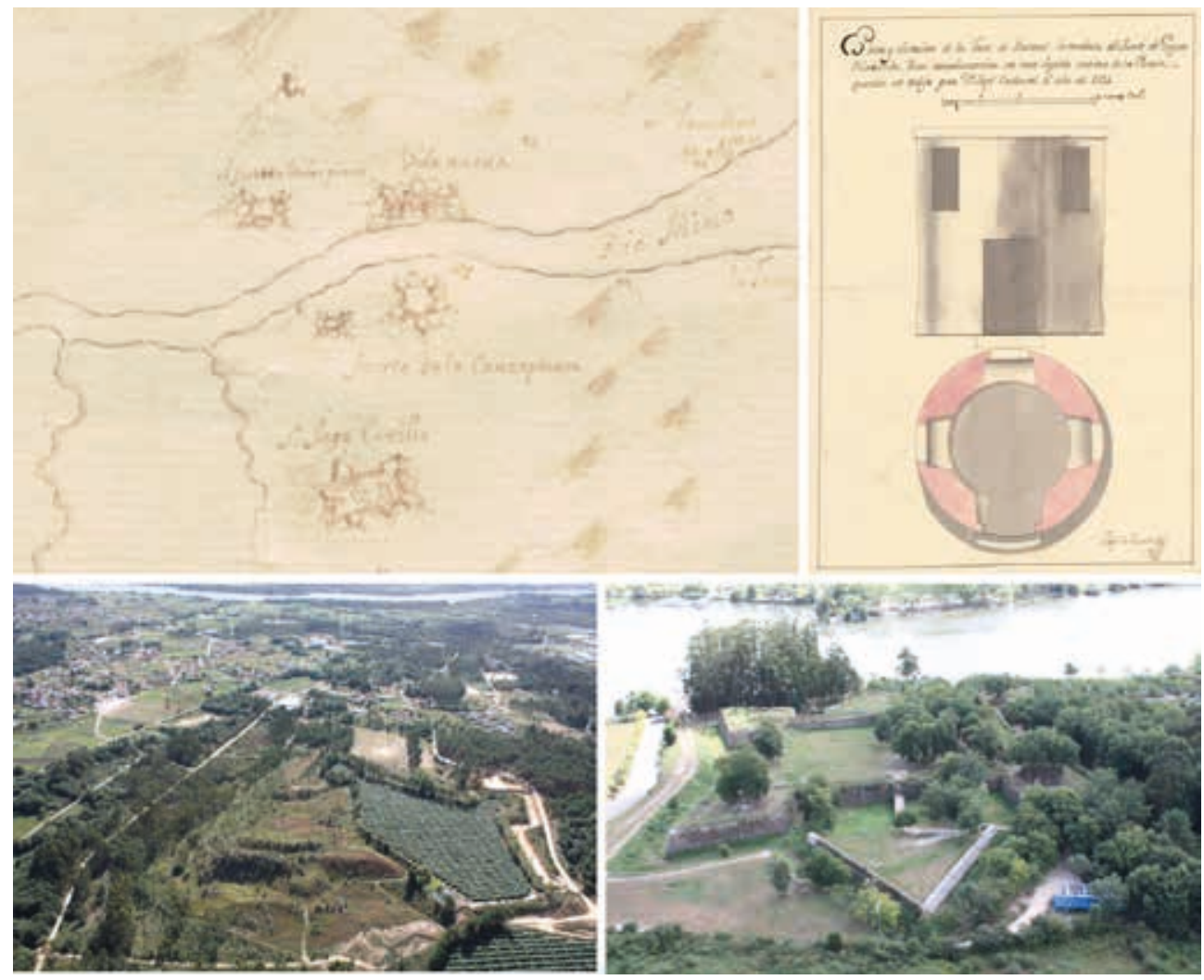

Figura 15. Arriba á esquerda, recorte do Mapa y diseño de la Frontera de Galicia (Arquivo do Museo Naval de Madrid —Signatura: MN-E-19-22; http://bibliotecavirtualdefensa.es/BVMDefensa/i18n/consulta/ resultados ocr. cmd? buscar cabecera=Buscar\&id=717\&tipoResultados=BIB\&posicion=69\&forma=ficha, consulta de 13/11/2018); á dereita, Plano, y elevación de la Torre de ratones inmediata del Fuerte de Goyan, de Josef La Fuente, recollido na Relación topográfica de las plazas, y puestos Fortificados del Reyno de Galicia de Miguel de Hermosilla, de 1800 (Biblioteca Central Militar — Localización: GF — Signatura: GF-MS-1/1; http://bibliotecavirtualdefensa.es/BVMDefensa/i18n/consulta/registro.cmd?id=16674, consulta de 05/04/2018). Abaixo á esquerda: forte de Medos, en Estás, e á dereita, forte de San Lourenzo, en Goián (proporcionadas por Terra Arqueos S. L.) 
Esta fortificación completábase co forte das Chagas, do cal se pensaba que non se conservaba nada; porén, grazas á análise dos datos LiDAR, púidose documentar a súa planta, baixo o arboredo de repoboación, practicamente enteira. Está situado a medio quilómetro cara ao norte, completando o dominio visual por este flanco cara ao río da fortaleza principal da Concepción. A planta corresponde a un cadrado con catro baluartes e dous revelíns ou medias lúas (figura 16).

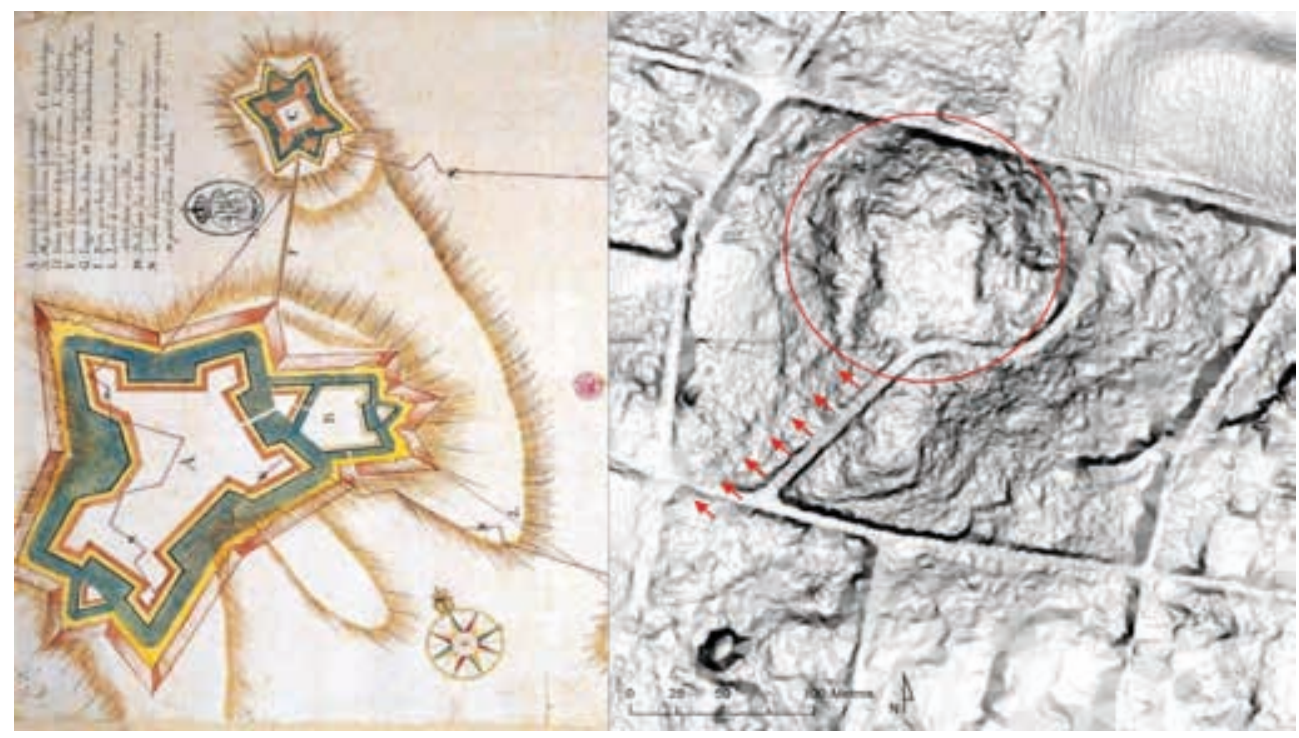

Figura 16. Á esquerda, recorte do plano histórico da Fortaleza de Nosa Sra. da Concepción, en Goián, atribuído por Garrido a Miguel de Lescol (aprox. 1664); á dereita, mapa de pendentes obtido a partir dos datos LiDAR da área na que se sitúa o forte das Chagas. Marcouse a liña de comunicación coa fortaleza de Nosa Sra. da Concepción cunhas frechas

Nunha eminencia situada en fronte do forte de Lovelhe denominada A Atalaia, sobre un xacemento romano, constrúese unha torre coñecida como torre dos Ratos, da cal conservamos unicamente a rocha cortada para a súa disposición na localización e o foso que rodeaba a eminencia. Non coñecemos a data de construción nin a súa autoría, pero varios autores apuntan a que se trataba dunha torre de vixilancia en relación co forte de San Lourenzo e o control do paso sobre o río Miño á altura de Lovelhe. Polo debuxo que se conserva de Joséf La Fuente na obra de Miguel de Hermosilla (figura 15), trataríase dunha torre de planta circular con tres ventás e unha porta, e estaría realizada en pedra con cantaría nos vans. 
Ademais de todas estas construcións, habería que engadir a torre dos Correa, que tampouco se conserva e sería de época anterior, e un sistema de trincheiras que comunicaba as fortificacións entre si, como se pode apreciar na figura 13. Aínda hoxe se observan parte destas trincheiras, que se dirixían directamente desde A Concepción e a torre dos Ratos até o río, de maneira que se podía acceder por elas desde os pasos de barcas cara á terra.

Fronte a este complexo sistema portugués con enclave en ambos os dous reinos (comunicados polos pasos de barcas), o exército español decide fortificarse a $3 \mathrm{~km}$ ao norte no lugar de Estás, cortando o paso cara a Tui. Constrúese alí o forte de Medos ou de Santiago Carrillo. Trátase dunha fortificación de campaña de grandes dimensións, formada por dous recintos (figura 15, imaxe inferior esquerda). O recinto norte é un reduto de planta irregular, con dous baluartes ao sur e cunha entrada defendida por unha media lúa. $O$ reduto sur é unha coroa con dous baluartes e un semi-baluarte polo lado sur. Estaba ademais rodeado por fosos e camiños cubertos. $\mathrm{Na}$ figura 15, pódese apreciar como desde o forte se dominan Vila Nova e Goián, que se localizarían no extremo superior dereito da fotografía, á altura da ponte internacional que cruza o río Miño.

Unha vez devoltas as prazas ao remate da guerra coa firma do Tratado de Lisboa en 1668, decídese desmantelar algunhas das construcións en terra, como sucedería aquí coas Chagas, A Barca ou Nosa Sra. da Concepción, e construír un novo forte de construción permanente máis próximo ao río que permita manter o control do paso fronteirizo. Levántase así o forte de San Lourenzo (figura 15, imaxe inferior dereita):

Que el fuerte de Goyan letra D donde antes estaba la Atalaya se haga todo de nuevo por ser puesto mas inmediato vatir con artillería y mosquetería a Villanueva, y que en el interin que se hace, se mantenga el fuerte letra B que llaman de las llagas y se desmantelará después que esté acabado el de Goyán, y para la fabrica de este puesto se podrá valer de los materiales del fuerte de la Concepción que se desara luego. 13 de agosto de 1688. Yo la Reina. (Soraluce, 1985: 179)

Os planos foron revisados polos enxeñeiros Carlos e Fernando Grunnenberg; a construción comezou en 1691 e finalizou en 1693. Trátase dun forte de planta 
cadrada con catro baluartes, tres revelíns protexendo as cortinas noroeste, suroeste e sueste, e foso que rodea o reduto e os revelíns.

$\mathrm{Na}$ figura 6, pode observarse como queda configurado o mapa do subsistema de Goián-Vila Nova de Cerveira-Medos. Coa ocupación desta zona, os portugueses dominan un dos accesos cara ao interior de Galicia e cara aos subsistemas veciños, ao SSO o da Guarda-Caminha e cara ao nordeste o de Tui-Valença. Cara a Tui, aínda que se levaron a cabo algunhas incursións por parte do exército portugués, os avances eran freados entre o forte de Medos e o de Amorín. No entanto, conseguiron penetrar polo val do Rosal para acabar ocupando A Guarda. Ademais, a serra de Argalo en Galicia e as da Gávea, Salgosa e Coba envolven este pequeno espazo, como se dunha comarca natural se tratase, que acaba permitindo a creación deste subsistema no que os portugueses dominan o lado sur da vía de tránsito e os galegos, o norte (véxase tamén a figura 17).

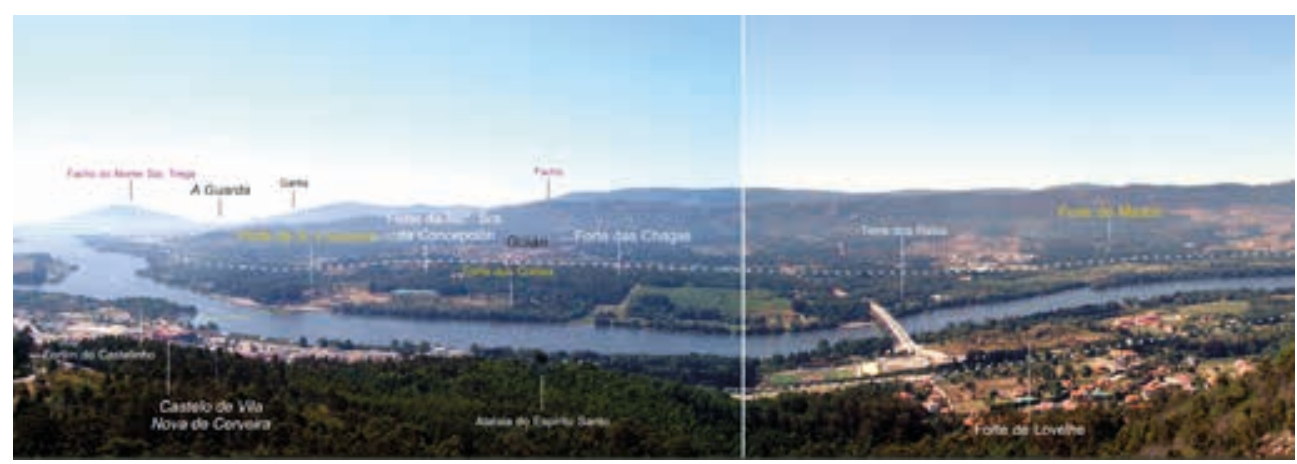

Figura 17. Desde o conxunto ou subsistema de Goián-Vila Nova de Cerveira-Medos, exércese un control directo dos pasos de barca sobre o Miño e das vías que descorren en paralelo ao río por ambos os territorios. O exército portugués entra por Goián, aséntanse e fai diversas incursións en Galicia, coma no caso da Guarda

\section{REVERSIÓN/RECEPCIÓN/INCLUSIÓN}

A raíz do traballo que teño a sorte de desenvolver desde hai anos na fronteira miñota, xorden varias reflexións na liña do impacto do que facemos como investigadoras e investigadores, que non sempre ten en conta as propias comunidades locais e os seus intereses. Como pouco, lévanos a pensar na dificultade entre a necesidade de conciliar a xestión patrimonial, con todo o que este concepto 
implica (e máis se o facemos desde a CVPC), como xa vimos, e os intereses das comunidades que conviven con ese (e viven ás veces dese) patrimonio. Por unha banda, temos a obriga desde a nosa profesión, mais tamén como sociedade, de coñecer e conservar o noso legado, e mantelo para as xeracións futuras, pero tamén de acrecentalo. Por outra, temos a obriga de contar coas comunidades locais, herdeiras directas, cando facemos isto.

Levo anos visitando e vivindo o Baixo Miño. Unha parte das miñas orixes vén do Rosal. En varias ocasións, asistín á conmemoración da toma de Goián por parte de Vila Nova de Cerveira. Eu percibina así como vou describir. Hai que dicir que esta vivencia é anterior á última gran reforma do forte de San Lourenzo (a creación do Espazo Fortaleza), cando este, escondido tras unha cortiña de árbores, lle daba as costas ao río. A finais de agosto, reproducindo o momento da toma de 1663, pola noite os nosos veciños e veciñas portugueses lanzan fogos artificiais desde Vila Nova e desde unha barca situada diante do Castelinho. Escóitase música ao lonxe, o estoupar dos fogos, as voces e os aplausos ao outro lado do río. Na beira galega, o silencio, apenas uns murmurios da xente. Situabámonos en fila empolicados ao muro que delimitaba a observar os fogos. Ao rematar a tirada, tamén en fila e nun silencio apenas roto de cando en vez por algún murmurio, iámonos ás nosas casas. Sempre me chamou a atención observar aquela escena; observar o contraste entre ambas as percepcións, a pesar da distancia de máis de tres séculos entre o feito histórico e a súa recuperación por parte das comunidades locais. En Galicia, ademais, a escena ocorría de costas á materialidade do conflito, o forte de San Lourenzo estaba oculto tras a pantalla de árbores e maleza e nin sequera asistía como espectador ao que alí pasaba; os seus veciños, Concepción, As Chagas, A Barca... estaban destruídos ou esquecidos nun curruncho da memoria. A re-significación desta paisaxe e os seus compoñentes, a recuperación do forte de San Lourenzo e a súa contorna, a súa apertura ao río e a construción dunha bancada no seu glacis iniciaron un novo proceso de patrimonialización, recuperaron a memoria esquecida e revertérona socialmente. Hoxe, haberá que comprobar se as percepcións dos asistentes mudaron tras o proceso de re-significación deste patrimonio e a xeración dun novo espazo para o diálogo, ou se, a pesar do esforzo, continúan sendo as mesmas.

Nos dous últimos anos, tiven a oportunidade de asistir a varias actividades centradas neste patrimonio que xa non xurdían desde os axentes implicados neste 
proceso de investigación, senón que proviñan desde comunidades locais coma o Instituto de Estudos Miñoráns ou a Asociación Sociocultural Senraia, ou os colexios CEIP de Sobrada (Tomiño) e CEIP Pintor Antonio Fernández de Goián. Son iniciativas moi distintas, pero cun obxectivo común: coñecer, valorizar e dar relevancia social ao patrimonio. Nestes casos, creo que estabamos no bo camiño.

Aínda así, cada vez que dotamos dun relato estes elementos e que recuperamos a súa memoria e iniciamos eses procesos de reversión social (que non sempre de inclusión social), os resultados poden ser moi variables. Igual ca en Goián, na vila da Guarda houbo un proceso, en certo modo parello ao de San Lourenzo, no forte de Santa Cruz. A historiadora da arte e directora de cine Sara Traba realizou no ano 2016 a curtametraxe $O$ castelo da froita (https://www.youtube.com/ watch?v=BbPdFtkstjw), baseada na fortaleza de Santa Cruz na Guarda e que foi presentada ao I Festival de Curtametraxes sobre o Patrimonio Arqueolóxico da Provincia de Pontevedra Telearqueoloxía 2016. Esta curtametraxe non se centraba tanto no forte coma na percepción que cinco personaxes reais (veciños e veciñas da Guarda) teñen del e, sobre todo, da súa recuperación unha vez que volveu a mans públicas e foi sometido a un proceso de restauración e rehabilitación. Cada un deles ten unha vinculación co castelo, normalmente indirecta (o avó, a nai, a avoa, a costureira...). Porén, todos eles o recordan por un elemento en común: a froita. E non todos teñen a mesma percepción, interese e sensación ante este proceso. Creo que o mellor peche ao que quería transmitir neste texto é recomendarvos que o vexades e, logo, reflexionedes sobre el, os personaxes e o que facemos na xestión patrimonial. A curta pecha moitas lecturas. Sobre todo, que non hai unha única lectura. Ao final, o patrimonio é multivocal e nós somos diversas e diversos. 


\section{REFERENCIAS BIBLIOGRÁFICAS}

Almeida, Carlos A. F. de (1968): Vias Medievais. I. Entre-Douro-e-Minho, Porto, ed. autor.

AlmeIDA, Ernesto Iglesias (1984): Los antiguos «portos» de Tuy y las barcas de pasaje a Portugal, Tui, ed. autor. ALMEIDA, Ernesto Iglesias (2013): «La Guerra de Independencia de Portugal en la frontera galaico portuguesa», Diversarum Rerum. Revista de los Archivos Catedralicio y Diocesano de Ourense, 8, 393-402.

Amado Reino, Xesús / David Barreiro / Felipe Criado-Boado / María del Carmen Martínez López (2002): «Especificaciones para una gestión integral del impacto desde la Arqueología del Paisaje», TAPA (Traballos de Arqueoloxía e Patrimonio), 26, Santiago de Compostela, Laboratorio de Patrimonio, Paleoambiente e Paisaxe.

ANDRADE, Amélia A. (1994): Vilas, poder régio e fronteira: o exemplo de Entre Lima e Minho medieval, tese de doutoramento en Historia da Idade Media, policopiada, Lisboa, Faculdade de Ciências Sociais e Humanas, Universidade Nova de Lisboa.

Andrade, Amélia A. (1998): «A estratégia dionisina na fronteira noroeste», Revista da Facultade de Letras. História, 15:1, 163-176.

Anschuetz, Kurt F. / Richard H. Wilshusen / Cherie L. Scheick (2001): «An Archaeology of Landscapes: Perspectives and Directions", Journal of Archaeological Research, 9:2, 157-211.

Ávila y La Cueva, Francisco A. (1852; ed. fac. 1995): Historia Civil y Eclesiástica de la Ciudad de Tuy y su Obispado. vols. 1-2, Santiago de Compostela, Consello da Cultura Galega.

Barreiro Martínez, David (2009): «Arqueología aplicada: la revalorización del patrimonio arqueológico», en III Seminario Internacional Municipio de Envigado. Gestión del Patrimonio Arqueológico, Envigado (Colombia), 4 de agosto de 2009 (comunicación, inédita).

Blanco-Rotea, Rebeca (2008): «El Castillo de la Palma (Mugardos, A Coruña). Un enclave defensivo en la Ría de Ferrol», TAPA (Traballos de Arqueoloxía e Patrimonio), 40, Santiago de Compostela, Instituto de Estudos Galegos Padre Sarmiento, CSIC.

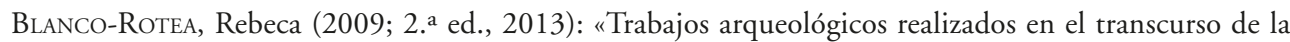
redacción del Plan Director de las Fortalezas Transfronterizas del Tramo Bajo del Río Miño", CAPA (Cadernos de Arqueoloxía e Patrimonio), 22, Santiago de Compostela, Grupo de Investigación en Arqueología del Paisaje, Universidade de Santiago de Compostela.

Blanco-Rotea, Rebeca (2011a): «Herramientas metodológicas aplicadas al estudio de un paisaje urbano fortificado: el caso de la villa de Verín (Monterrei, Ourense)», en María Domingo Fominaya / Antonio J. Sánchez Luengo (dirs. e coords.), Arqueología aplicada al estudio e interpretación de edificios históricos. Últimas tendencias metodológicas, Madrid, Ministerio de Cultura, 179-197.

Blanco-Rotea, Rebeca (2011b): «Las fortificaciones de Goián-Vila Nova de Cerveira-Medos en el territorio fortificado transfronterizo galaico-portugués», Revista Castillos de España, 58 (164-165-166), 139-145.

Blanco-Rotea, Rebeca (2015): Arquitectura y paisaje. Fortificaciones de frontera en el sur de Galicia y norte de Portugal, tese de doutoramento, Vitoria-Gasteiz, Universidad del País Vasco.

Blanco-Rotea, Rebeca (2017): «Arquitectura y paisaje. Aproximaciones desde la arqueología», Arqueología de la Arquitectura, 14: e051 (doi: http://dx.doi.org/10.3989/arq.arqt.2017.007).

BLANCO-RotEA, Rebeca (2018): «Paisajes urbanos modernos de la frontera galaico-portuguesa. La fortificación de las villas y ciudades en el siglo XVII», Monográfico «Cidade (in)defesa», Revista de História da Arte, 13, $10-35$. 
BouzA, Fernando Jesús (1991): «Primero de diciembre de 1640: ¿̨una revolución desprevenida?», Manuscrits. Revista d Història Moderna, 9, 205-225.

BouZA, Fernando Jesús (1993): «1640 perante o Estatuto de Tomar. Memória e Juízo do Portugal dos Filipes», Penélope. Fazer e desfazer história, 9/10, 17-27.

Caballero Zoreda, Luis (1995): «Método para el análisis estratigráfico de construcciones históricas o "lectura de paramentos" ", Informes de la Construcción, 46:435, 37-46.

CADIVAFOR (2008): Catalogación, Digitalización y Valoración de las Fortalezas Defensivas de la Frontera de Galicia Norte de Portugal, Ferrol, CIEFAL, CIS Galicia, E. S. Gallaecia.

Cobos-Guerra, Fernando (2005): «Los sistemas de fortificación como patrimonio heredado», en Alicia Cámara (coord.), Los ingenieros militares de la monarquía hispánica en los siglos XVII y XVIII, Madrid, Ministerio de Defensa / Asociación Española de Amigos de los Castillos / Centro de Estudios Europa Hispánica, 271-291.

Cobos-Guerra, Fernando (2011): «El sistema de fortificaciones abaluartadas de la raya hispano portuguesa como patrimonio de la humanidad. Caracterización y valoración del sistema. Estado de la cuestión», Castillos de España, 58 (164-165-166), 155-166.

Cobos-Guerra, Fernando / Antonio Hoyuela Jayo (2005): «Metodología de estudio e intervención del Plan Director de las fortalezas fronterizas del Bajo Miño», en Alfredo González Ruibal (coord.), Actas del III Congreso de Castellología Ibérica (28 de octubre-1 de noviembre, Guadalajara), Madrid, Asociación Española de Amigos de los Castillos / Diputación de Guadalajara, 695-715.

CostA, Fernando Dores (2005): «Interpreting the Portuguese War of Restoration (1641-1668) in a European Context», e-JPH, 3:1, 1-14.

Criado-Boado, Felipe (1996a): «El futuro de la arqueología, ¿la arqueología del futuro?», Trabajos de Prehistoria, 53:1, 13-26.

Criado-Boado, Felipe (1996b): «Hacia un modelo integrado de gestión de investigación y gestión del Patrimonio Histórico: la cadena interpretativa como propuesta», Boletín del Instituto Andaluz del Patrimonio Histórico, 16, 73-78.

CRIADO-BOADO, Felipe (1999): «Del terreno al espacio: planteamientos y perspectivas para la arqueología del paisaje», CAPA (Cadernos de Arqueoloxía e Patrimonio), 6, Santiago de Compostela, Grupo de Investigación en Arqueología del Paisaje, Universidade de Santiago de Compostela.

Criado-Boado, Felipe (2012): Arqueológicas. La razón perdida, Barcelona, Edicións Bellaterra S. L.

Ericeira, Conde da (1945): História de Portugal Restaurado, Porto, Livraria Civilização.

Fernández de Medrano, Sebastián (1700; ed. fac. 2001): El arquitecto perfecto en el arte militar, Bruxelas, Casa de Lamberto Marchant (ed. fac., Valladolid, Editorial MAXTOR).

Ferreira Priegue, Elisa (1988): «Los caminos medievales de Galicia», Boletín Auriense, Anexo 9.

GÁNDARA, Felipe de la (1677): Nobiliario, armas, y triunfos de Galicia, hechos heroicos de sus hijos, y elogios de su nobleza, y de la mayor de España y Europa, Madrid, Julián de Paredes.

Garrido Rodríguez, Jesús (2004): Fortificaciones del río Miño, memoria histórica inédita realizada durante os traballos de redacción do Plan Director Fortrans, Vigo.

González Méndez, Matilde (1999): Investigación y puesta en valor del Patrimonio Histórico. Planteamientos y Propuestas desde la Arqueología del Paisaje, tese de doutoramento da área de Humanidades e Ciencias Sociais, inédita/cd-rom, Santiago de Compostela, Universidade de Santiago de Compostela.

Heilen, Michael P. (2005): An Archeological Theory of Landscapes, Arizona, The University of Arizona. 
Jones, David M. (2010): The Light Fantastic. Using airborne lidar in archaeological survey, Swindon, English Heritage, Customer Services Department.

Knapp, A. Bernard / Wendy Ashmore (1999): «Archaeological Landscapes: Constructed, Conceptualized, Ideational», en Wendy Ashmore / A. Bernard Knapp (eds.), Archaeologies of Landscape. Contemporary Perspectives, Malden (Massachusetts), Blackwell, 1-30.

Llobera, Marcos / Pastor Fábrega-Álvarez / César Parcero-Oubiña (2011): «Order in Movement: a GIS approach to accessibility", Journal of Archaeological Sciences, 38, 843-851.

Lock, Gary R. I Zoran STANCIC (1995): Archaeology And Geographic Information Systems: A European Perspective, London, Taylor \& Francis.

LuCuZE, Pedro de (1772): Principios de fortificación, que contienen las definiciones de los terminos principales de las obras de Plaza, y de Campaña, con una idea de la conducta regularmente observada en el Ataque, y Defensa de las Fortalezas, Barcelona, Thomas Piferrer.

Matos, João Barros (2016): «As fortalezas abaluartadas de Mazagão, Ceuta e Diu. Implantação e relação com o território", en Francisco J. Rogado Contente Domingues (ed.), Actas do XXIV Colóquio de Histórica Militar "Nos 600 Anos da Conquista de Ceuta - Portugal e a Criação do Primeiro Sistema Mundial», Lisboa, Comissão Portuguesa de História Militar, 27-39.

Pallares, María del Carmen (1987): «Sistema feudal y proceso de urbanización: algunas reflexiones a propósito del caso gallego en los siglos XII y XIII", en Jubilatio-Homenaje de la Facultad de Geografía e Historia a los Profesores D. Manuel Lucas Álvarez y D. Ángel Rodríguez González, Santiago de Compostela, Universidade de Santiago de Compostela, t. I, 95-105.

PAllares, María del Carmen / Ermelindo Portela (2015): «Para una lectura histórica del paisaje. La impronta medieval», en Gerardo Pereira Menaut / Ermelindo Portela Silva (eds.), El territorio en la historia de Galicia. Organización y control. Siglos I-XXI, Santiago de Compostela, USC / Editora Académica, 97-151.

PARKER, Geoffrey (2002): La revolución militar. Innovación militar y apogeo de occidente 1500-1800, Madrid, Alianza Editorial, S. A.

Pérez Alberti, Augusto (1986a): «El relieve», en María Pilar de Torres Luna (dir.), Geografía de Galicia. Volumen I: El medio fisico, A Coruña, Xuntanza Editorial, 19-197.

Pérez Alberti, Augusto (1986b): «La red fluvial. Su importancia en el modelado», en María Pilar de Torres Luna (dir.), Geografia de Galicia. Volumen I: El medio fisico, A Coruña, Xuntanza Editorial, 349-421.

Quirós, Juan Antonio / Sonia GobBato (2004): «Prospección y arqueología de la arquitectura», Arqueología Espacial, 24-5, 185-215.

SAntos Solla, Isabel / Xosé Manuel Santos Solla (1996): «O Baixo Miño», en Francisco Rodríguez Iglesias (ed.), Galicia Xeografía. Tomo XIX, Vales do Tambre e do Ulla, Rías Baixas pontevedresas e Baixo Miño, A Coruña, Hércules de Ediciones, 381-513.

Soraluce Blond, José R. (1985): Castillos y fortificaciones de Galicia: la arquitectura en los siglos XVI-XVIII, A Coruña, Fundación Pedro Barrié de la Maza.

SILVA, Luís Augusto Rebello da (1860): Historia de Portugal nos séculos XVII e XVIII, tomos I, II e III, Lisboa, Imprensa Nacional.

Vecoña, María (2006): Descubrir a historia. Plan director das fortalezas transfronteirizas do Baixo Miño, Santiago de Compostela, Xunta de Galicia, Consellería de Cultura e Deporte, Dirección Xeral de Patrimonio. 
Viveen, Willem / Jorge Sanjurjo-Sánchez / Ana Goy-Diz / Antonie Veldkamp / Jeroen M. Schoorl (2014): «Paleofloods and ancient fishing weirs in NW Iberian rivers», Quaternary Research, 82, 56-65.

Wheatley, David (1995): "Cumulative Viewshed Analysis: a GIS-based method for investigating intervisibility, and its archaeological application», en Gary Lock / Zoran Stancic (eds.), Archaeology and GIS: A European Perspective, London, Routlege, 171-185.

Wheatley, David / Mark Gillings (1999): «Vision, Perception and GIS: some notes on the development approaches to the study of archaeological visibility", en Gary Lock / Zoran Stancic (eds.), Beyond the map. Archaeology and Spatial Technologies, Amsterdam, IOS Press, 1-27.

Whittlesey, Stephanie M. (1997): «Archaeological landscapes: A methodological and theoretical discussion», en Stephanie Whittlesey / Richard Ciolek-Torrello / Jeffrey H. Altschul (eds.), Vanishing River: Landscapes and Lives of the Lower Verde Valley. The Lower Verde Valley Archaeological Project: Overview, Synthesis, and Conclusions, Tucson, SRI Press, 17-28. 